\title{
Applicability, Feasibility and Efficacy of Phytotherapy in Aquatic Animal Health Management
}

\author{
Ram Prakash Raman \\ Aquatic Environment \& Health Management Division, ICAR-Central Institute of Fisheries Education Panch Marg, Andheri (W), \\ Versova, Mumbai, India \\ Email: rpraman1@gmail.com
}

How to cite this paper: Raman, R.P. (2017) Applicability, Feasibility and Efficacy of Phytotherapy in Aquatic Animal Health Management. American Journal of Plant Sciences, 8, 257-287.

http://dx.doi.org/10.4236/ajps.2017.82019

Received: September 12, 2016

Accepted: January 19, 2017

Published: January 22, 2017

Copyright $\odot 2017$ by author and Scientific Research Publishing Inc. This work is licensed under the Creative Commons Attribution International License (CC BY 4.0).

http://creativecommons.org/licenses/by/4.0/

\begin{abstract}
The use of chemotherapeutants, antibiotics, and pesticides in aqua farms and non-adherence to scientific management practices have resulted in adverse impact on aquacultural production, serious outbreaks of diseases, development of drug resistance in microbes, and accumulation of antibiotics and pesticide residues in finfish and shellfish and environmental pollution. As a result, a need has been felt by the aquaculturists as well as aquatic animal health management professionals to find a suitable alternative therapy in place of antibiotics and chemotherapy. Phytotherapy has come to be recognized as a handy and viable alternative to chemotherapy, as it is economical, effective, non-resistance forming, renewable, eco-friendly and farmer-friendly. Although the use of medicinal plants is known to humanity since the dawn of human civilization for the treatment and control of human and animal diseases but its importance in combating finfish and shellfish diseases has been realized only recently. The phytotherapy of aquacultural diseases is in its infancy in most part of the world except in China to some extent. However, many important contributions in this field by different workers during the last quarter of the $20^{\text {th }}$ century and early $21^{\text {st }}$ century have shown encouraging results and opened new vistas in phytotherapy of aquatic animals. The present review crtically evaluates the present status of knowledge of phytotherapy in the world combating various aquacultural diseases, identifying the bottlenecks and suggests remedial measures.
\end{abstract}

\section{Keywords}

Phytotherapy, Finfish and Shellfish, Microbial and Parasitic

Diseases in Aquaculture, Immunostimulants, Biopesticides 


\section{Introduction}

Phytotherapy is the oldest form of healthcare known to mankind. It has been used for treatment of humans and animals since thousands of years. In fact, long before humans knew anything about diseases, plants knew how to treat them. Herbal treatment has been an integral part of the development of modern civilization. The knowledge of phytotherapy is built upon the experiences of several generations, often of several centuries, and the data upon which it is based have been often obtained at a price in human lives.

Medicinal plants are the treasures of our planet. In India the use of medicinal plants for treatment of various diseases and ailments dates back to the times of Rig Veda written between 4500-1600 B.C. Some of the legendary works on use of medicinal plants for treatment of various diseases were pioneered by great ancient Indian physicians like Sushrut, Charak, Chakradatta, Vagbhata, Vangsena, Bhavaprakasha etc. The Charak Samhita written at 1000 B.C. gives comprehensive details of therapeutic use of medicinal plants. In 2735 B.C., the Chinese emperor Shen Nung wrote an authoritative treatise on herbs that is still in use today. The records of King Hammurabi of Babylon (c.1800 B.C.) include instructions for using medicinal plants. In c.400 B.C. first Greek herbal was written and in c.100BC first illustrated herbal was produced in Greece. By c.50 A.D., Roman Empire spread herbal medicine and commerce of plants around the Empire. The entire Middle East has a rich history of herbal healing. There are texts surviving from the ancient cultures of Mesopotamia, Egypt, and India that describe and illustrate the use of many medicinal plant products. In the scriptural book of Ezekiel, which dates from the sixth century B.C., we find this admonition regarding plant life. By the seventeenth century, the knowledge of herbal medicine was widely disseminated throughout Europe. The first U.S. Pharmacopeia was published in 1820. This volume included an authoritative listing of herbal drugs, with descriptions of their properties, uses, dosages, and tests of purity. It was periodically revised and became the legal standard for medical compounds in 1906. In 1900s A.D. the BHMA produced the British Herbal Pharmacopoeia.

At present more than $25 \%$ of the prescribed modern medicines in the world are made from medicinal plants. The World Health Organization (WHO) estimates that $80 \%$ of the world's population living in developing countries of Asia, Africa and Latin America, still relies on herbal medicines as its major source of primary health care. There are over 750,000 plants on the planet earth. However, up till now, only $5 \%$ of the plants species have been screened for biological activity. India is one of the world's 12 leading biodiversity countries blessed with 16 agro-climatic zones, 45,000 different plant species and 15,000 medicinal plants that included 7000 plants sourced by Ayurveda, 700 by Unani medicine, 600 by Sidha, 450 by Homoeopathy and 30 by modern medicine. According to an all India ethnobiological survey carried out by the Ministry of Environment \& Forests, Government of India, there are over 8000 species of medicinal plants being used by the people of India [1]. Despite accounting for only 2.5 per cent of the total land area, India houses over eight per cent of the recorded species. 
Herbal medicine is a type of medicine that uses roots, stems, leaves, flowers, or seeds of plants to improve health, prevent disease, and treat illness. It includes herbs, herbal preparations and finished herbal products that contain as active ingredients, parts of plants, or other plant materials or combinations. The medicinal plants produce a large number of organic chemicals of high structural diversity which are called secondary metabolites. Some of them are produced for self-defense [2]. The secondary metabolites are divided into three different categories based on their mechanism of function, i.e., chemotherapeutic, bacteriostatic, bactericidal, and antimicrobial [3]. The herbal extracts and herbal medicines are called "Rasayan" in Ayurvedic literature which have been used since time immemorial to treat and control numerous diseases of bacterial, viral, fungal and parasitic etiologies [4]-[11] like skin diseases, cough, cold, fever, headache, migraine, eye infections, respiratory tract infections, diarrhea, hepatotoxicity and anticancer, antistimulant, neurostimulant antiaging, antireumatic, adaptogenic, and antistress etc [12] [13] and a host of many other ailments [14] [15]. There are estimated to be around 25,000 effective plant based formulations are available in the indigenous medical texts in India and around 10,000 designed.

\section{Health Challenges in Aquaculture}

Disease, decay and death have always coexisted with life whether it is human, animal, fish or for that matter any organism. It is, therefore, imperative that treatments of diseases must also have been contemporaries with the dawn of human intellect. Like any animal including humans, fishes also suffer from a variety of diseases caused by pathogens and parasites viz. microbes including virus, bacteria and fungi; protozoan and metazoan parasites including helminths, nematodes, annelids, mulluscans and arthropods. The infectious diseases account for $60 \%$ of the fish production loss in aquaculture ponds. Fishes are coldblooded animals; consequently, they suffer from many environmental and stress-related diseases as well. Besides, there are many nutritional diseases also. The outbreak of diseases jeopardizes regular aquaculture and threatens aquaculture production. Because fish are schooling aquatic animals, they are hard to observe individually, making the diagnosis and treatment of disease difficult. Therefore, controlling disease is one of the most vital tasks in aquaculture. With ever increasing intensification, finfish and shellfish farming have suffered from serious outbreaks of diseases in the recent past. Unscientific management practices together with irrational use of synthetic (unnatural) chemicals and therapeutics have had disastrous implications on aquacultural production due to catastrophic outbreaks of diseases. Recently the world aquaculture has encountered two major dreaded diseases: (i) Epizootic Ulcerative Syndrome (EUS) in finfish and (ii) White Spot Syndrome virus (WSSV) in prawns. So catastrophic are these two diseases that they have endangered almost the majority of fish and prawns population and their survival itself is threatened [7] [8].

These diseases (together with many others) have led to tremendous produc- 
tion and economic losses to fish farmers, aqua-entrepreneurs and fish workers whose livelihood entirely depended on aquaculture or related enterprise. Every year millions of dollars worth of finfish and shellfish produce are lost due to diseases worldwide.

Off late aquaculturists the world over have heavily relied on the use of antibiotics, synthetic drugs, chemotherapeutants and pesticides to combat the disease problems facing the aquaculture industry. In India itself fish farmers use a large number of pesticides like nuvan, malathion, eldrin, BHC, ekalux, cypermethrin, parathion, trichlorophon, diuron, etc. to control the ectoparasites of fish. Due to this, pesticide resistance and bioaccumulation of pesticide have also been noticed. Future is ominous for the connoisseurs of fish so much exposed to pesticides. The advocates of pesticides must realize that to argue that we must use pesticides to feed a growing population is like saying we need to feed you even if it means poisoning to death. Farmers have also resorted to reckless use of antibiotics in fish ponds. Due to this, large numbers of cases of antibiotic resistant strains of bacteria have come to light [16] [17] [18]. Germs are winning the war against diseases. Fish farmers are facing the challenge of drug resistant bacterial pathogens, which have stopped responding to most of the conventional antibiotics [19]. Besides, there is the problem of bioaccumulation of antibiotics in the fish body. Off late, several consignments of seafood mostly cultured shrimps exported from India have been rejected by many EU countries due to the presence of antibiotic residues in them resulting in considerable economic losses to the seafood exporters. Moreover treatment with antibiotics, pesticides or other sources of chemotherapy involves very high cost to the aqua-farmers and many times cost of medicine is higher than the cost of the fish to be saved.

In this grim situation, the aqua-farmers the world over have started searching for novel and effective alternative therapy from renewable resources. Phytotherapy has come as a handy and viable alternative to chemotherapy. Herbal medicines are effective, economic, eco-friendly and farmer friendly, easily biodegradable, non-habit forming, non-resistance forming, non-narcotic, and without much side effects. Besides, the raw materials are inexpensive, renewable, locally available, user friendly, and can be easily prepared [20].

\section{Phytotherapy in Aquaculture}

The application of Phytotherapy in field of fish and fisheries is a relatively new area of research which is still in its infancy. The rapid detection and identification of fish pathogens is crucial for successful disease control in an aquafarm. The herbs may be used in many ways such as garden fresh, dried, powdered, juices, or extracted (in various solvents like water, alcohol, acetone, ether, etc), or essential oils. The herbal medicines are applied either as decoctions (individual) or concoctions (mixed) or in combination with other drugs for effective fish health management [21]. In India, "Mrgayurveda", a branch of Ayurveda deals with animal life and treatment of animal diseases by herbal medicines. One Indian plant that is most studied world wide, is Azadirachta indica A. Juss (syn. 
Melia azadirachta). A cornerstone of the Ayurvedic tradition, neem is known as "sarva roga nivarak" or "healer of all ailments" in India. Not surprising, that the people of India regard neem tree as "village pharmacy". United Nations has declared Neem as the "Tree of the 21st Century". Its medicinal and pesticidal effects are well documented. Preliminary studies have revealed that water soluble part of alcoholic extract of $A$. indica leaves possessed hypoglycemic, hypolipidemic, hepatoprotective, antifertility, hypotensive and anti-serotonin activity [22] [23] [24] [25] [26]. Beside neem, many other herbs like turmeric (Curcuma longa), tulsi (Ocimum sanctum), garlic (Allium sativum), Adhatoda vasica [7] etc. have also been used to treat aquacultural diseases. Chinese system of phytotherapy is quite popular among Chinese fish farmers who have taken lead in herbal treatment of finfish and shellfish diseases in the Asian region.

Off late in China, use of antibiotics to prevent and cure aquacultural diseases, has been modified by addition of herbal medicines with feed or culture medium [27]. The fish farmers are using various Chinese herbal therapies to control diseases and getting good results. For example, in Zhejiang Province, Euphorbia humifusa and Acalypha australis are used for enteritis and in Guangdong Province, Thysanospermum diffusum is used to cure bacterial kidney disease, gill rot, and enteritis [28]. The Institute of Hydrology, Academia Sinica, China has reported promising results with the application of Chinese tallow tree (Sapium sebiferum) with Chinese rhubarb (Rheum officinale) for "white-head-and-whitemouth" disease and bacterial gill rot. For control of hemorrhagic septicemia in fish, decoction of Chinese rhubarb (Liguidambar taiwaniana) is given with feed for 5 consecutive days with successful results [28] Erythroderma is a common disease of grass carp and black carp in China which is caused by Pseudomonas fluorescens. It has been found that Chinese gall (Galla chinensis) applied @ 2-4 ppm controls erythroderma [28]. Enteritis is also common among grass carp, black carp (Mylopharyngodon piceus), bighead (Aristichthys nobilis) and common carp which is believed to be caused by Aeromonas hydrophila f. intestinalis. The enteritis has been successfully controlled by the use of a number of herbal medicines mixed into feeds, they are as follows : (1) Decoction of Chinese gall @ 2 - 3 ppm, Garlic @ 1 - 2 kg/100g fish daily for 6 consecutive days; or (2) Euphorbia australis@ $500 \mathrm{~g}$ dry herb or $2.5 \mathrm{~kg}$ fresh herb for $100 \mathrm{~kg}$ fish daily for 3 consecutive days; or (3) Acalypha australis-500g dry herb or $2 \mathrm{~kg}$ fresh herb per $100 \mathrm{~kg}$ fish daily for 3 consecutive days; or (4) Water knotweed (Polygonum hydropiper) -500 g dry herb or $2 \mathrm{~kg}$ fresh herb for $100 \mathrm{~kg}$ fish once daily for 3 consecutive days; (5) Andrographis paniculata-2 kg dry herb or $3 \mathrm{~kg}$ fresh herb for $100 \mathrm{~kg}$ fish for 5 - 7 days; (6) Fresh Portulaca oleracea @ 1.5 - $3 \mathrm{~kg} / 100 \mathrm{~kg}$ fish; or (7) Artemeisia argyi @ 100 g powder of A. argyi and Polygonum hydropiper $500 \mathrm{~g}$ powder or $1 \mathrm{~kg}$ fresh per 10,000 fingerlings; or fresh mock strawberry (Duchesnea indica)@ 1 kg/100kg fish [29]. Bacterial gill rot affects grass carp, black carp, bighead, common carp and other fishes; grass carp is the main victim. It has been successfully controlled by the use of following herbal medicines: (1) add dry powder of Chinese tallow tree (Sapium sebiferum) leaves to pond 
water to a concentration of $6.25 \mathrm{ppm}$; (2) add powder of Chinese rhubarb (Rheum officinale) to pond to a concentration of 2.5 - $3.7 \mathrm{ppm}$; (3) add Chinese gall to pond to a concentration of 2 - $4 \mathrm{ppm}$; (4) spread a solution of maple leaves over the pond; and (5) add Chinese sweet gum:water @ 2:1 [28].

The fish farmers of Bangladesh practice a unique system of plant-based aquaculture wherein bamboo stems and branches, jute sticks, the remains of sugarcane stalks, and/or tree branches are used as substrate. The various stalks are inserted vertically into the pond bottom, where they are colonized by the plankton, microbes, invertebrates and other organisms that make up periphyton. Fish graze on these concentrated forms of food more efficiently and the periphyton mats improve the water quality of the pond [30]. In this system fish production of $2305 \mathrm{~kg} / \mathrm{ha}$ could be achieved within 90 days using Indian major carps catla, Catla catla; rohu, Labeo rohita; and L. calbasu [31]. Similar practices have also been known in West Africa where it is called as Acadja, in Bangladesh it is known as Katha, and in Cambodia Samarah [32]. In fact, people of Nalbari district of Assam province of India use juice of betel nut and paan (locally known as Peek) for determining the quality of water with quite good results.

The various herbal-based therapeutic measures adopted for the treatment and control of different diseases of finfish and shellfish, and fish health management can be categorized as follows:

\subsection{Antibacterial}

Herbs are nature's own antibiotics. Many herbal medicines and medicinal plant extracts have been tried to treat and control the bacterial diseases and bacterial pathogens of finfish and shellfish. Dey and Chandra [33] showed that fry of Indian major carp, Catla catla when treated with $2 \%$ aqueous extract of an herbal formulation, were resistant to induced infection of Aeromonas hydrophila, and had higher neutrophil and lymphocyte counts than the untreated controls. Dey and Chandra [34] reported successful control of Epizootic Ulcerative Syndrome (EUS) in fish by applying turmeric and lime in affected fish ponds at 5 - 7 days intervals. Hota and Dey [35] studied the effect of turmeric (Curcuma longa) extract on some fish pathogenic bacteria and found that it has antibacterial effect on two important fish pathogens viz. Aeromonas and Staphylococcus. C. longa contains curcumene, tumerone, and turmerol. Its methanilic extract exhibits antibacterialactivity against Micrococcus luteus, Enterococci faecali, and Staphylococcus aureus [36]. Curcuminoids and gingerols have been reported to have antimicrobial, antifungal, anti-inflammatory, and antioxidant activities [37], [38]. Its rhizome is used to cure pimples, whitening of skin, and also as blood purifier [39].

Chopra et al. [40] showed that oil from the leaves, seeds and bark of neem Azadirachta indica possesses a wide spectrum of antibacterial action against Gram-negative and Gram-positive microorganisms, including $M$. tuberculosis and streptomycin resistant strains. In vitro it inhibits Vibrio cholerae, Klebsiella pneumoniae, M. tuberculosis and M. pyogenes [41] [42] [43]. Antimicrobial ef- 
fects of neem extract have been demonstrated against Streptococus mutans and S. faecalis. Extracts from stem bark of neem A. Indica is active against Klebsiella, Staphylococcus, and Serratia species [44]. Nim 76, a product from neem oil showed inhibitory effect on the growth of various pathogens including bacteria, fungi and virus. Some of the bioactive compounds responsible for neem's antibacterial property are nimbidin [45], nimbin, nimbinin, nimbidinin, nimbidic acid [46], nimbolide [47] [48]; mahmoodin [49]; margolone, margolonone and isomargolonone [50]. Das et al. [51] tested Aquaneem, an emulsified product prepared from the neem against four pathogenic bacteria of fish viz. Aeromonas hydrophila, Pseudomonas fluorescens, Escherichia coli and Myxobacteria spp. and found that their growth were remarkably inhibited. Similar observations have been made by Sahu et al. [52] with aquaneem as effective fish bactericide. Das et al. [51] recommended $10 \mathrm{ppm}$ of aquaneem for pond application in culture system for control of bacterial diseases of fish such as haemorrhagic septicaemia, fin rot and tail rot, bacterial gill disease and dropsy like conditions. The antibacterial herbal product extracted from Solanum trilobum, Andrographis paniculata, and Psoralea corylifolia bio-encapsulated in Artemia and fed to PL of $P$. monodon enhanced the survival rate of post larva when grown in water containing shrimp bacterial pathogen [53].

$\mathrm{Xu}$ et al. [54] reported that the aqueous extract of Chinese herbal medicines showed antibacterial activity against shrimp bacterial pathogens. Jin et al. [55] tested fifteen Chinese herbal medicines against Vibrio harveyi causative agent of skin ulcer disease in sea-perch out of which three herbal medicines from Rhizoma sanguisorbae, Pericarpium gramati and Frucrus schizandrae were most effective against the pathogenic bacteria. Sun et al. [56] conducted a comparative study on the impact of dietary furazolidon and a Chinese herbal medicine Portulaca oleracea L. in fat greenling (Hexagrammos otakii) saffected with bacterial gill rot disease. They reported $90 \%$ survival in fishes fed with herbal medicine Portulaca oleracea, while those fed with furazolidon supplemented diet could achieve 65\% survival. Shuming et al. [57] reported 85\% cure from bacterial septicemia in Carassius auratus by applying Chinese herbal medicines composed of Scutellaria baicalensis, Herba euphorbiae applied @ 2\% to 4\%. Zheng et al. [58] tested the efficacy of 15 Chinese herbal medicines on Vibrio alginolyticus, a pathogen of vibriosis of large yellow croaker, Pseudosciaena crocea (Richardson) out of which 4 herbal medicines viz. Pericarpium granati, Rhizoma sanguisorbae, Fructus schizandrae, Rheum officinale were most effective.

Raman [7] has found remarkable antibacterial activity of Indian medicinal plant vasa (Adhatoda vasica) against Psudomonas fluorescens, a virulent and ubiquitous fish pathogen involved in many bacterial diseases of fish. The Holy basil Tulsi (Ocimum sanctum) has also potent antimicrobial properties [59]. It inhibits the growth of E. coli, B. anthracis, M. tuberculosis [60]. It is useful in respiratory tract infection, bronchitis, chronic cough and gastric diseases of children. The Ursolic acid present in tulsi has anti-allergic properties. A variety 
of biologically active compounds have been isolated from the tulsi leaves including ursolic acid, apigenin, eugenol and luteolin. The essential oil of tulsi also has antibacterial properties [61]. Its oil is rich in vitamin C, carotene, calcium and phosphorus. Immanuel et al. [62] reported that butanolic extracts of terrestrial herbs Ricinus communis, Phyllanthus niruri, Leucus aspera, Manihot esculenta; and sea weeds Ulva lactuca and Sargassum wightii when tested against shrimp pathogen Vibrio parahaemolyticus, and fed with herbal extracts enriched Artemia; boosted the survival, specific growth rate and also lowered $V$. parahaemolyticus load in muscle and hepatopancreas tissues of treated Penaeus indicus juveniles. Bhuvaneswari and Balasundaram [63] screened ethanolic extracts of Acalypha indica, Acorus calamus, Coleus aromaticus, Heliotropium indicum, and Indigofera aspalathoides for antibacterial activity against Aeromonas hydrophila. They found that A. calamus and $I$. aspalathoides warded off the growth of the pathogen completely at minimum inhibitory concentrations of 1.29 and $2.16 \mathrm{mg} / \mathrm{l}$, respectively suggesting that herbs can replace antibiotics against bacterial infection in fish. Chakraborty et al. [64] have extracted compounds like labda-14-ene 3a, 8alpha-diol and labda-14ene-8alpha-hydroxy-3one from sea lettuce Ulva fasciata which were inhibitory to the growth of marine aquacultural pathogen Vibrio parahaemolyticus.

Besides these herbs, there are large number other medicinal plants, which have been studied extensively for their antibacterial properties against human and animal pathogens and thus have promising value against pathogenic bacteria of fish and shellfish. Some important among them are as follows (Table 1). The list of antibacterial herbs is quite exhaustive to suffice in the limited space in this paper. These and other time tested medicinal plants could be evaluated against different bacterial pathogens of fish.

\subsection{Antiviral}

The viral diseases take heavy toll of finfish and shellfish stocks annually. Holi basil Tulsi (Ocimum sanctum) has antiviral properties [59]. Ayurvedic Tulsi preparations have significantly reduced the symptoms of viral hepatitis. Rao [84] made an attempt to treat white spot disease successfully with turmeric powder (Curcuma longa), Phyllanthus neruri, and Clicanthus nutans. Applying neem extract to the culture pond soil also minimized white spot disease outbreak [85]. Citarasu et al. [86] studied the effect of methanolic extracts of five Indian medicinal plants viz. Cyanodon dactylon, Aegle marmelos, Tinospora cordifolia, Picrorhiza kurooa and Eclipta alba on WSSV challenged Penaeus monodon. They observed that those shrimps which were not fed with this herbal diet (control), died within seven days upon challenge with WSSV, while those fed with herbal supplemented diets had 74\% survival and reduction in viral load. Much work on antiviral effect of herbs in fish has not been carried out. However, the works done on medicinal plants against animal viruses may be investigated for application against viral pathogens of finfish and shellfish. Some important antiviral herbals are presented in Table 2 . 
Table 1. Antibacterial activity of some medicinal plants.

\begin{tabular}{|c|c|c|c|}
\hline S. No. & Name of Plant & Name of Bacteria & Author \\
\hline 1 & Vitis adnata (Essential oil) & Salmonella pullorum & Srivastava, 1996 [65] \\
\hline 2 & Cymbopogon citrates (Oil) & $\begin{array}{l}\text { Shigella flexneri, E. coli, Staphylococcus aureus, } \\
\text { Salmonella typhi and Klebsiella pneumoniae }\end{array}$ & Syed et al., 1995 [66] \\
\hline 3 & Chamaesyce hirta & S. flexneri & Vijaya and Ananthan, 1996 [67] \\
\hline 4 & Ipomea fistulosa (Ethanolic extract) & Streptococcus faecalis & Chowdhury et al., 1997 [68] \\
\hline 5 & Cabbage juice & S. aureus & Kyung and Fleming, 1997 [69] \\
\hline 6 & Anacardium occidentale & S. aureus and Serratia marcescens & Sathwane et al. 1997 [70] \\
\hline 7 & Bhallatakasava and Sukshma Triphala & Clostridium titani & Kulkarni et al., 1995 [71] \\
\hline 8 & Eucalyptus oil & Mycobacterium avium & Leite et al., 1998 [72] \\
\hline 9 & Centella asiatica & $\begin{array}{l}\text { Bacillus subtilis, E. coli, } P \text {. aeruginosa } \\
\text { and Psendomonas cichorii }\end{array}$ & Srivastava et al., 1997 [73] \\
\hline 10 & $\begin{array}{c}\text { Terminalia bellerica, Garcinea } \\
\text { gummigulla, Anisomeles malabarica, } \\
\text { Aegle marmelos, Alangium } \\
\text { saluifolium and Zizyphus jujuba }\end{array}$ & B. subtilis, $S$. aureus, E. coli and $P$. aeruginosa & Valsaraj et al., 1997 [74] \\
\hline 11 & Azadirachta indica & $\begin{array}{l}\text { Wide spectrum antibacterial action against } \\
\text { Gram-negative and Gram-positive microorganisms, } \\
\text { including } M \text {. tuberaulosis and } \\
\text { streptomycin resistant strains. }\end{array}$ & $\begin{array}{l}\text { Chopra et al., } 1952 \text { [40]; } \\
\text { Patel and Trivedi, } 1962 \text { [41]; } \\
\text { Satyavati et al., } 1976 \text { [42]; } \\
\text { Ahmad et al., } 1995 \text { [43] }\end{array}$ \\
\hline 12 & Ocimum sanctum & E. coli, B. anthracis, M. tuberculosis & Bhargava, and Singh, $1981[60]$ \\
\hline 13 & Gloriosa superb (leaf extract) & S. aureus $B$. subtilis, $K$. pneumoniae and $E$. coli & Subashini et al., 2000 [75] \\
\hline 14 & $\begin{array}{l}\text { Triphala churna, Hareetaki churna, } \\
\text { Dashmula churna }\end{array}$ & $\begin{array}{l}\text { S. epidermidis, } P . \text { vulgaris, } S \text {. aureus, } \\
\text { E. coli, } P \text {. aeruginosa and } S . \text { typhi. }\end{array}$ & Tambekar and Dahikar, 2011 [76] \\
\hline 15 & $\begin{array}{l}\text { Moringa oleifera } \\
\text { (leaf extract) }\end{array}$ & B. cereus, B. subtilis, $S$. aurens, $S$. infea and $M$. phlei & Pal et al., 1995 [77] \\
\hline 16 & Calotropis procera (Ethanolic extract) & Enterobacter cloacae and Fusarium moniliforme & Jain, et al., 1996 [78] \\
\hline 17 & Adhatoda vasica & Pseudomonas fluorescens & Raman, 2004 [7] \\
\hline 18 & $\begin{array}{c}\text { Pericarpium granati, } \\
\text { Rhizoma sanguisorbae, Fructus } \\
\text { schizandrae, Rheum officinale }\end{array}$ & Vibrio alginolyticus & Zheng et al., 2005 [58] \\
\hline 19 & $\begin{array}{l}\text { Acorus calamus and } \\
\text { Indigofera aspalathoides }\end{array}$ & Aeromonas hydrophila & $\begin{array}{l}\text { Bhuvaneswari and } \\
\text { Balasundaram, } 2006 \text { [63] }\end{array}$ \\
\hline 20 & Ulva fasciata & $V \cdot$ parahaemolyticus & Chakraborty et al., 2007 [64] \\
\hline 21 & Allium sativum & $\begin{array}{l}\text { Aeromonas hydrophila infection in } \\
\text { Rohu fish Labeo rohita }\end{array}$ & $\begin{array}{l}\text { Sahu et al., 2007a } \\
{[79]}\end{array}$ \\
\hline 22 & Magnifera indica kernel & $\begin{array}{l}\text { Aeromonas hydrophila infection in } \\
\text { Rohu fish Labeo rohita }\end{array}$ & $\begin{array}{l}\text { Sahu et al., 2007b } \\
{[80]}\end{array}$ \\
\hline 23 & $\begin{array}{c}\text { Azadirachtin from } \\
\text { Neem Azadiracta indica }\end{array}$ & $\begin{array}{l}\text { Aeromonas hydrophila infection } \\
\text { in goldfish Carassius auratus }\end{array}$ & $\begin{array}{l}\text { Kumar et al., 2012a [81], } \\
\text { 2012b [82], } 2013 \text { [83] }\end{array}$ \\
\hline
\end{tabular}

\subsection{Antifungal}

The use of synthetic fungicides to control fish diseases has been restricted due to their carcinogenicity, teratogenicity, high and acute toxicity, long degradation period and their effect on food and health hazards for human beings. In recent 
Table 2. Antiviral activity of some medicinal plants.

\begin{tabular}{|c|c|c|c|}
\hline S. No. & Name of Plant & Name of virus & Author \\
\hline 1 & Neem extract & $\begin{array}{c}\text { Vaccinia virus } \\
\text { Chikungemya and Measles Virus } \\
\text { Coxsackie Virus }\end{array}$ & $\begin{array}{c}\text { Rao et al., } 1969 \text { [87] } \\
\text { Gogati and Marathe, } 1989 \text { [88] } \\
\text { Badam et al., } 1999 \text { [89] }\end{array}$ \\
\hline 2 & $\begin{array}{c}\text { Maclura cochinchinensis, } \\
\text { Centella asiatica, Mangifera indica, } \\
\text { Cynometra cloiselli, C. madagascariensis, } \\
\text { Evonymopsis longipes, Ravensara retusa and } \\
\text { Terminalia monoceros Acorus calamus extracts }\end{array}$ & Herpes Simplex Virus & $\begin{array}{c}\text { Bunyapraphatsara et al., } 1999 \text { [90] } \\
\text { Yoosook et al., } 1999 \text { [91] }\end{array}$ \\
\hline 3 & Syzygium kurzi, S. megacarapum (extract) & Encephalitis Causing Virus & Chandra et al., 1998 [93] \\
\hline 4 & $\begin{array}{c}\text { Scilla hyacianthiana, Dillemia pomifera, } \\
\text { Smilax perfoliadour and Rosa osmastonii (extract) }\end{array}$ & $\begin{array}{l}\text { Semilike Forest Virus (SFV) } \\
\text { and Ranikhet Diseases Virus (RDV) }\end{array}$ & Rana and Joshi, 1998 [94] \\
\hline 5 & $\begin{array}{l}\text { Cyanodon dactylon, Aegle marmelos, Tinospora } \\
\text { cordifolia, Picrorhiza kurooa and Eclipta alba }\end{array}$ & $\begin{array}{l}\text { WSSV challenged } \\
\text { Penaeus monodon }\end{array}$ & Citarasu et al. (2006) [86] \\
\hline 7 & Ocimum sanctum (extract) & Anti-viral property & Janssen et al., 1989 [59] \\
\hline 8 & $\begin{array}{l}\text { Geranium sanguineum } \\
\text { polyphenolic (extracts) }\end{array}$ & $\begin{array}{l}\text { Various strains of Human, } \\
\text { Avian and Equine Enfluenza Virus }\end{array}$ & Serkedjieva, 1996 [95] \\
\hline 9 & $\begin{array}{l}\text { Hyptianthera stricta } \\
\text { (Ethanolic extract) }\end{array}$ & $\begin{array}{l}\text { Encephalomyocarditis and } \\
\text { Japanese Encephalitis Virus }\end{array}$ & Saxena et al., 1997 [96] \\
\hline 10 & $\begin{array}{l}\text { Cyanodon dactylon, Aegle marmelos, Tinospora } \\
\text { cordifolia, Picrorhiza kurooa and Eclipta alba. }\end{array}$ & $\begin{array}{l}\text { WSSV challenged } \\
\text { Penaeus monodon }\end{array}$ & Citarasu et al. 2006 [86] \\
\hline 11 & $\begin{array}{l}\text { Anti-WSSV drugs (MP07X) derived from the marine } \\
\text { plant and (TP22C) derived from terrestrial plant). }\end{array}$ & $\begin{array}{l}\text { White spot syndrome virus (WSSV) } \\
\text { infected Litopenaeus vannamei }\end{array}$ & $\begin{array}{l}\text { Chakraborty and Ghosh, } \\
2013 \text { [97] }\end{array}$ \\
\hline 12 & Anti-WSSV drug (TP22C) derived from terrestrial plants & $\begin{array}{l}\text { White spot syndrome virus (WSSV) } \\
\text { infected shrimp Litopenaeus vannamei }\end{array}$ & $\begin{array}{l}\text { Ghosh and Chakraborty, } \\
2013[98]\end{array}$ \\
\hline
\end{tabular}

years, many phyto-extracts have been used as fungicides for the control of various fungal pathogens of finfish and shellfish due to their high antifungal properties, nontoxic nature, easy availability at low cost and with no side effects. Xu et al. [54] reported that aqueous extract of a Chinese herb, Fructus prunusis showed promising results in inhibiting the growth of Fusarium oxysporum which caused black gill disease in $P$. orientalis. Auro-de-Ocampo and Jimenez [99] showed that the extracts of Helenium quadridentatum were quite effective in controlling saprolegniasis in fish. Followings are some of the important works carried out on the antifungal effect of medicinals plants, which may have significant value for controlling fungal pathogens of finfish and shellfish:

Extract of neem leaf, oil and seed kernel have been found highly effective against certain fungi including Trichophyton, Epidermophyton, Micrsporum, Trichosporon, Geotircum and Candida [100] [101] Hexane extract of neem leaves and its chromatographic fractions exhibited significant antifungal activity against deuteromyceteous fungal pathogen [102]. The bioactive compounds of neem responsible for antifungal property of neem have been found as nimbidin [103] gedunin [104] cyclic trisulphide and cyclic tetrasulphide [105] and 10-undecyn-1-01 [102]. The Eucalyptus oil has been observed to have significant antifungal activity. Butanol and ethyl acetate extracts of Calotropis procera was found highly effective against Candida albicans (Table 3). 
Table 3. Antifungal activity of some medicinal plants.

\begin{tabular}{|c|c|c|c|}
\hline S. No. & Name of Plant & Fungal Pathogens & Author \\
\hline 1 & Fructus prunusis & $\begin{array}{c}\text { Black gill disease in farm shrimp } \\
\text { P. orientalis caused by Fusarium oxysporum }\end{array}$ & Xu et al., 1993 [54] \\
\hline 2 & $\begin{array}{l}\text { Helenium quadridentatum } \\
\text { (Extract) }\end{array}$ & Saprolegniasis in fish & $\begin{array}{l}\text { Auro-de-Ocampo and } \\
\text { Jimenez (1993) [99] }\end{array}$ \\
\hline 3 & Neem leaf (Extract), oil and seed & $\begin{array}{l}\text { Human fungi including Trichophyton, } \\
\text { Epidermophyton, Micrsporum, } \\
\text { Trichosporon, Geotircum and Candida } \\
\text { Deuteromyceteous fungal }\end{array}$ & $\begin{array}{l}\text { Khan and Wassilew, } 1987 \text { [100]; } \\
\text { Biswas et al., } 2002[101] \\
\text { Govindachari et al.,1999 [102] }\end{array}$ \\
\hline 4 & $\begin{array}{l}\text { Turmeric and lime in affected } \\
\text { culture ponds at 5-7 days duration. }\end{array}$ & EUS disease in fish. & Dey and Chandra, 1994. [33] \\
\hline 5 & $\begin{array}{c}\text { Garlic }(2 \mathrm{~kg})+\text { Salt }(2 \mathrm{~kg})+\mathrm{CuSO}_{4}(20 \mathrm{~g})+\mathrm{KMnO}_{4} \\
(20 \mathrm{~g}) \text { mixed into a paste form which is added } \\
\text { in } 30-50 \text { litre of water and sprayed over pond } \\
\text { surface of } 1.33 \text { ha area. }\end{array}$ & EUS disease in fish. & $\begin{array}{c}\text { Goswami et al., } 2006 \\
{[106]}\end{array}$ \\
\hline 6 & Turmeric oil & Dermatophytic fungi, Trichophyton rubrum & Apisariakul et al., 1995 [107] \\
\hline 7 & $\begin{array}{c}\text { The essential oil from the leaves of } \\
\text { Chenopodium ambrosioides }\end{array}$ & $\begin{array}{l}\text { antimycotic activity against } \\
\text { Trychophyton mentagrophytes and } \\
\text { Microsporum audouinii at } 50 \mathrm{ppm}\end{array}$ & Kishore et al., 1996 [108] \\
\hline 8 & Garlic clove extract & Fusarium solani. & $\begin{array}{c}\text { Alice and Sivaprakasam, } \\
1999[109]\end{array}$ \\
\hline 9 & Leaf extract of Bauhinia variegata & Aspergillus fumigatus and $A$. niger & Sharma and Saxena, 1996 [109] \\
\hline 10 & $\begin{array}{l}\text { Methanolic extract of rhizome } \\
\text { of Nelumbo nucifera }\end{array}$ & Potent antifungal and antiyeast activity. & Mukherjee et al., 1995 [111] \\
\hline 11 & $\begin{array}{l}\text { E. citriodora, E. dalrympleana and } \\
\text { E. laveopinea (Essential oil) }\end{array}$ & six Dermatophytes & Shahi et al., 1999 [112] \\
\hline 12 & E. citriodora & Pyricularia grisea & Mishra et al., 1997 [113] \\
\hline
\end{tabular}

\subsection{Antiprotozoal}

Protozoan parasites are ubiquitous in fisheries world whether it is inland or marine. They take heavy toll of finfish and shellfish particularly during their early life cycle from egg to fry and fingerling stages. They also infect the adult stage but mortality is less frequent than the infant stage.

Dey and Chandra [34] reported successful control of Trichodinosis in the seed (fry) of Indian major carp, Catla catla. They reported a severe incidence of Trichodinosis in a catla fry population in some nursery ponds caused by a ciliate protozoa Trichodina indica. The prevalence of the infection was $60 \%-70 \%$ of the fry population. The infection was on the general body surface and fins. They could control the infection by applying $1 \mathrm{ppm}$ aqueous extract of garlic and 10 $\mathrm{ppm}$ common salt $/ \mathrm{ha} / \mathrm{m}$ water. Works done in Chinese aquaculture, reports that reproduction of Trichodina can be inhibited by adding $15-20 \mathrm{~kg} / \mathrm{mu}$ of chinaberry (Melia azadirach) leaves once a week. Sprinkling $25-30 \mathrm{~kg} / \mathrm{mu}$ of a decoction of fresh chinaberry branches and leaves is also effective [28]. Oketch-Rabah et al. [114] isolated two antiprotozoal compounds namely mazanzagenin and nyasol from Asparagus africanus and found the nyasol potently inhibits the growth of Leishmania major and Plasmodium falciparum. 


\subsection{Antihelminthic}

Helminthic worms are significant parasites of fish. The worms of the class monogenea are mostly ectoparasitic with no intermediate host involved in the life cycle while the digneneans are endoparasitic with a life cycle involving at least one intermediate host. Nematodes are also parasitic in fish requiring at least one other host to complete their life cycle. Other important group of worms parasitizing the fish is Acanthocephala. In acanthocephalans at least one intermediate host is required to complete the life cycle.

Mitchell and Hoffman [115] reported that Kamala, an ancient antiheminthic herbal medicine fed at $0.1 \%$ of the diet for three days if dry rations are being fed, or up to seven days if wet rations are fed, removes adult cestodes and other worms from fishes. The dose prescribed is $1 \mathrm{~g} / \mathrm{kg}(45 \mathrm{~g} / 100 \mathrm{lb})$ of fish per day for 7 to 14 days [116]. Ayurvedic system of medicine prescribes that flower; fruit, twig, seed, pulp and oil of neem eliminate helminthiasis in animals [101]. According to Neeraja and Narayana [117] Neemol, an ethanol extract of neem seed kernels has been found very effective against cestode parasites in white leghorns. Jangde et al. [118] tested antihelminthic property of two plants viz. Artemesia maritima and Butea frondosa against Haemonchus controtus worms in bullock and found that aqueous extracts of both these plants are highly effective in immobilizing and killing of the worms. The combination of these plants further reduced motility and death time.

\subsection{As Biopesticide}

Several plant species have insecticidal and pesticidal property. Many of them are highly effective against metazoan ectoparasites. Rajasekaran et al. [119] reported that oil of Tulsi (O. sanctum) has been used as a potent anti-malarial drug. Essential oil of Tulsi has been reported to possess $100 \%$ larvicidal activity against the Culex mosquitoes. Its extracts have marked insecticidal activity against mosquitoes. It also has mosquito repellent properties.

Shaoqui [28] reports a novel method for control of lernaeasis of carps in China. Adding $400 \mathrm{~kg} / \mathrm{mu}$ of fermented cow dung or pig manure or $100-150 \mathrm{~kg} / \mathrm{mu}$ of distiller's dregs for every meter of water depth successfully controls lernaeasis in carp. The pine (Pinus massoniana) applied @ $20 \mathrm{~kg}$ per 1/15 ha water area, also controls Learnaeasis [29]. Recently, Tiwari et al. [120] reported that stems of banana plant put squarely in the fish pond with small amount of kerosene oil, controls aquatic insects in nursery ponds.

Neem (Azadirachta indica) is the classic example of biopesticide. It has been identified by WHO/UNEP as environmentally "powerful" natural pesticide. Vietmeyer [121] sees Neem as a tree solving global health problems. Off late several biopesticides made of neem, either singly or in combination with other plants, have hit the market; some notable among them are: Achook (Godrej Agrovet), Neem Gold (SPIC), Neem Guard (Akshay Chem), Neemark (West Coast Herbchem), Margocide (Monofix \& Co.), Jawan crop protector (MCDA Agro), Field Marshal (Khetiwadi Corner), Wellgrow (ITC Ltd.), Neemol (Meen- 
al Oil \& Agro Industries), Nethrin (Amitul Agrochem), Sukrina (Conster Pvt. Ltd.), Aquaneem, Neemta 2100, Nimin etc. Srinivasan et al. [122] tested, neem products like "Neem Azal", "Nimbecidine", "Neem Gold" against whitefly, Bemisia tabaci and reported that all neem products gave effective control against whitefly. Paruthi et al. [123] tested a neem based pesticide called "Achook" against root-knot nematode, Meloidogyne incognita and observed $90.7 \%$ reduction in larval hatch at 1.0 percent concentration. Clinical studies with the dried neem leaf-extract indicate its effectiveness to cure ringworm and eczema and scabies [101]. In an experiment to test the molluscicidal property of neem based pesticide like achook, nimbecidine and azadirachtin against snails Lymnaea acuminata and Indoplanorbis exustus, Singh et al. [124] observed that molluscicial effect was time and dose dependent. The toxic effect of azadarachtin against both snails was greater than synthetic molluscicides. Recently, Kumar et al. [81] [82] tested effect of Azadirachtin on Argulus parasites of ornamental fish Carassius auratus and found that Azadirachtin @ 15 ppm is very effective in killing the Argulus spp. Similarly, Kumar et al. [125] tested Piperine on Argulus spp. parasites on Carassius auratus and reprted $100 \%$ killing of these parasites with piperine @ 5 ppm. Osuala and Okwousa [126] found that neem stem bark extract was lethal against three common snails Biomphalaria pfeifferi, Bulinus truncatus and Lymnaea natalensis. Bail et al. [127] also screened some of the medicinal plants for their molluscicidal activity against snails. Dimetry and El-Hawary [128] tested a product from neem seed kernel called "Neem Azal-F" against aphid Aphis craccivora and found that the product inhibited the growth and reproduction of the aphids. Ganapragasam et al. [129] tested a neem-based pesticide called "Jawan" against some nematode pests and reported 100 percent kill at 10 - 20 dilution of the product. In an experiment on combined effect of curcumin (from turmeric) and 1-cysteine, nemicidine, nemol and vimicidine (all from neem), Gangopadhyay [130] reported significant antifungal and insect repellent activity.

Beside neem, several other plants like cedar Cedrus deodar, Pongamia sp., Eucalyptus sp., Acorus sp., garlic (Allium sativum), ginger (Zingiber officinale), Dialium guineese, Nerium indicum, mahua oil, Karanj oil, Momordica charantia, Pandanus odoratus, camphor (Cinnamomumum camphora), C. zeylanicum, Szygium aromaticum, Cympobogon citratus, Derris sp., Annona muricata, Jatropa elliptica, Renealmia exaltata, Chenopodium ambrosiodes, Ruta chalepensis, Vaccaria pyramidata, Thevetia peruviana, Ocimum spp. etc, have significant insecticidal and pesticidal properties (Table 4).

\subsection{As Immunostimulant}

The use of immunostimulant in aquaculture has opened a new vista in fish health protection. It has proved to be an effective means of increasing immunopotency of fish. So far, a large number of immunostimulants, that include a very heterogenous group of substances like synthetic chemicals, biological substances, mycelial fungi, killed mycobacterium, polysaccharides, glucans, peptidoglycan, 
Table 4. Herbs as biopesticide.

\begin{tabular}{|c|c|c|c|}
\hline S. No. & Name of biopesticide/plant & Effect & Author \\
\hline 1 & Neem Azal, Nimbecidine, Neem Gold & Toxic to whitefly, Bemisia tabaci & Srinivasan et al., 2001 [122] \\
\hline 2 & Neem Azal-T/S & Toxic to Gambusia affinis & El-shazly and El-sharnoubi, 2000 [131] \\
\hline 3 & Neem Azal-F & Toxic to Aphid, Aphis craccivora & Dimetry and El-Hawary, 1995 [128] \\
\hline 4 & Achook (neem based pesticide) & $\begin{array}{l}\text { Toxic to Root-knot nematode } \\
\text { Meloidogyne incognita }\end{array}$ & Paruthi et al., 1996 [123] \\
\hline 5 & Neem leaf-extract & Kills Ringworm, Eczema and Scabies & Biswas et al., 2002 [101] \\
\hline 6 & Achook, Nimbecidine and Azadirachtin & $\begin{array}{l}\text { Kills snails Lymnaea acuminata } \\
\text { and Indoplanorbis exustus }\end{array}$ & Singh et al., 1996 [132] \\
\hline 7 & Neem stem bark extract & $\begin{array}{l}\text { Kills snails Biomphalaria pfeifferi, } \\
\text { Bulinus truncatus and Lymnaea natalensis }\end{array}$ & Osuala and Okwousa, 1993 [126] \\
\hline 8 & Neem-based pesticide "Jawan" & Toxic to Nematode pests & Ganapragasam et al., 1993 [129] \\
\hline 9 & $\begin{array}{l}\text { 1-cysteine, nemicidine, nemol and } \\
\text { vimicidine (derived from neem plant) }\end{array}$ & Antifungal and Insect Repellent & Gangopadhyay, 1995 [130] \\
\hline 10 & $\begin{array}{l}\text { Azadirachtin derived from } \\
\text { Neem Azadirachta indica }\end{array}$ & $\begin{array}{l}\text { Argulus parasite of goldfish } \\
\text { Carassius auratus }\end{array}$ & $\begin{array}{l}\text { Kumar et al., } 2012 \text { [81] } \\
\text { Kumar et al., } 2013 \text { [82] }\end{array}$ \\
\hline 10 & Curcumin (derived from turmeric) & Antifungal and Insect Repellent & Gangopadhyay, 1995 [130] \\
\hline 11 & Rotenone (derived from Derris root) & $\begin{array}{l}\text { Erdication of unwanted fish, } \\
\text { affects respiratory system, fatal. }\end{array}$ & Medda et al., 1995 [133] \\
\hline 12 & Croton tiglium & Piscicidal & Babu, 1965 [134] \\
\hline 13 & Milletia pachycarpa & Piscicidal & Bhuyan, 1968 [135] \\
\hline 14 & Justicia hayatai & Fish poison & Ohta et al., 1969 [136] \\
\hline 15 & Barringtonia acutangula & Fish poison & Chakraborty et al., 1972 [137] \\
\hline 16 & Randia dumetorum & Fish poison & Nandy and Chakraborty, 1976 [138] \\
\hline 17 & Marchantia polymorpha & Piscicidal & Kanasaki and Ohta, 1976 [139] \\
\hline 18 & Zanthoxylum armatum fruits & Piscicidal & Ramanujam and Ratha, 1980 [140] \\
\hline 19 & Mahua oil cake & Piscicidal & Bhatia, 1970 [141] \\
\hline 20 & $\begin{array}{l}\text { Logs of Pala and bamboo plants } \\
\text { immersed in pond water }\end{array}$ & Controls fish lice (Argulus spp.) & Goswami et al., 2006 [106] \\
\hline 21 & Piperine derived from Piper longum & Argulus parasite of goldfish Carassius auratus & Kumar Abhay et al., 2012 [125] \\
\hline
\end{tabular}

peptides, muramyl dipeptide, nutritional factors, hormones, cytokinins, and animal and plant extracts/ingredients like Azadirachtin, Piperine, Curcumin, Ocimum sanctum, Aloe vera extracts etc have been tested on the immune response in a variety of finfish and shellfish species [142] [143] [144]. However, the knowledge on the use of plant extracts and herbal medicines as immunostimulants is in its infancy, even though such botanical products are a rich source of active substances for immunotherapy [145].

Herbal drugs are known to possess immunomodulatory properties and generally act by stimulating both specific and non-specific immunity [146] [147] [148]. Many plants used in traditional medicine are reported to have immunomodulating activities. Some of these stimulate both humoral and cell mediated immunity while others activate only the cellular componenets of the immune 
system, i.e. phagocytic function without affecting the humoral or cell mediated immunity [149] [150]. Scores of medicinal herbs have been tested and tried with good results, in the control of different diseases of fish and shellfish [151] [152]. In the past few years the medicinal plants investigated for their immunostimulatory response on fish include Ocimum sanctum, Acalypha indica, Phyllanthus niruri, Phyllanthus emblica, Azadirachta indica, Crossandra infundibuliformis, Aloe vera, Curcuma longa, Solanum trilobatum, Piper betle, Murraya koenigi, and Mentha piperita [153], turmeric [20]; Chinese herbs Astragalus membranaceus, Polygonum multiflorum, Isatis tinctoria, Glycyrrhiza glabra, Lonicera japonica [154] [155], Massa medicata, Crataegi fructus, Scutelaria baicalensis, Artemisia capillaries, Cnidium officinale [156].

The immunomodulatory properties of Holi Basil, Tulsi (O. sanctum) have been studied in detail by many workers [157] [158] [159] [160], Das et al. [144]. The leaf of $O$. sanctum contains water soluble phenolic compounds, and various other constituents such as eugenol, methyl eugenol and caryophyllene [23] that might act as a potential immunostimulant. Essential oil of Ocimum sanctum was found to have anti-allergic properties. When administered to laboratory animals, the compound was found to inhibit mast cell degranulation and histamine release in the presence of allergen. These studies reveal the potential role of $O$. sanctum extracts in the management of immunological disorders including allergies and asthma. It is also anti-inflammatory due to the eugenol present in the leaves. Venkatalakshmi and Dinakaran Michael [159] have reported that active ingredients of leaves of Tulsi are responsible for antibody response and promote nonspecific defense mechanisms. Working on immunostimulantatory effect of Ocimum sanctum, Dinakaran [153] observed that frozen, lyophilized and sodium benzoate preserved leaf extract of Ocimum sanctum enhanced antibody response to Aeromonas hydrophila while the sodium benzoate preserved extracts enhanced neutrophil activity in Tilapia [159] [160]. The protective ability of $O$. sanctum is mediated through both specific and non-specific immune mechanisms, as evident from the enhanced antibody production and enhanced activation of neutrophils.

Turmeric also has several components with immunomodulatory and antioxidant properties [161] [162]. Immunostimulatory activity of neem (Azadirachta indica) has also been widely studied. The neem has been found to enhance immune response in healthy rats [163] [164], mice [165] [166] and immunocompromised hen [167]. Logambal and Michael [168] reported that $A$. indica enhances primary and secondary immune response in Tilapia Oreochromis mossambicus. The aqueous extract of neem leaf possesses potent immunostimulant activity as evidenced by both humoral and cell-mediated responses [169] [170]. Neem oil has also been shown to possess immunostimulant activity by selectively activating cell-mediated immune mechanisms to elicit an enhanced response to subsequent mitogenic or antigenic challenge. Kiran Kumar [171] studied the immunostimulatory effect of Catheranthus roseus, Calotropis gigantea and Datura stromoneum on Cyprinus carpio and found that C. roseus was more im- 
munostimulatory followed C. gigantea and D. stromoneum. Rao and Chakrabarti [172], Chakravarti and Rao [173], Rao et al. [174] [175] have made a detailed study on the effect of dietary supplementation of Achyranthes aspera (family: Amaranthaceae) on the immunological response, antigen clearance and survivality of Indian major carps and found that Achyranthes aspera stimulates immunity and increases resistance to infection.

Chuntao et al. [154] studied the response of a herbal immunoregulation mixture (HIRM) comprising of extracts of the following traditional Chinese medicines (TCMs): Astragalus membranaceus, Polygonum multiflorum, Isatis tinctoria, Glycyrrhiza glabra. The results showed that, compared with those in the control group, the diets with $0.5 \%$ and $1 \%$ HIRM resulted in significant increase in macrophage phagocytic activity, macrophage ROS and the levels of total protein, globulin, albumin and NOS activity in serum indicating that the herbal mixture elevated the immunity in carp (Cyprinus carp). Seung-Cheol et al. [156] studied the effects of dietary medicinal herbs: Massa medicata, Crataegi fructus, Artemisia capillaries, Cnidium officinale, and a mixture of all the herbs, on growth and non-specific immunity in juvenile red sea bream Pagrus major. The results revealed that medicinal herbs and herbal mixture enhanced the growth and non-specific immunity of red sea bream. Ardo et al. [155] studied the impact of Chinese herbs Astragalus membranaceus and Lonicera japonica extracts on the immune response of Nile tilapia (Oreochromis niloticus) challenged with Aeromonas hydrophila and observed that these herbs enhanced the immune response and disease resistance of cultured fish.

Although, these and many other plant extracts have been used as immunostimulants in fish, further studies are required to be conducted to find out the exact active ingredients responsible, and their mode of action. Further, most of the immunostimulants have been used mainly against bacterial diseases, the role of these immunostimulants against viral pathogens of finfish and shellfish is still not clear. Siwicki et al. [176] has stated that the best way of administration of immunostimulants to farm grown fish is to incorporate them in feed. Table 5 summerises various immunostimulants and its impact on aquatic animals.

\subsection{As Nutraceuticals}

Many herbs incorporated with regular diets of fish have shown better growth and help in minimizing the onset of diseases. Dey and Chandra [34] reported to have raised disease resistant fry of Indian major carp, Catla catla through treatment with $2 \%$ aqueous extract of a herbal formulation. Treated spawn had better growth during 35 days of rearing, better survival, higher food consumption and better health status than untreated controls. Kavitha [189] demonstrated impact of herbs Satavari (Asparagus racemous) and Chandrasoor (Lepidium sativum) @ $2 \mathrm{~g} / \mathrm{kg}$ fish/day in promoting growth in Indian major carp Labeo rohita. Kumar [190] reported Ashwagandha (Withania somnifera) applied @ $0.08 \mathrm{~g} / \mathrm{kg}$ fish/day in the diet of mrigal (Cirrhinus mrigala) resulted in a weight gain of $45.14 \%$. In subsequent studies Mulethi (Glycyrrhiza glabra Linn.) and Kali musli (Curculigo 
Table 5. Herbs as immunostimulant.

\begin{tabular}{|c|c|c|c|}
\hline S. No. & Name of Plant/product & Type of Immunostimulatory acivity & Author \\
\hline 1 & Glycyrrhizin (Glycosylated saponin) & $\begin{array}{l}\text { Anti-inflammatory, anti-tumour } \\
\text { and immunostimulatory activities. }\end{array}$ & Wada et al., 1987 [177] \\
\hline 2 & Glycyrrhizin & $\begin{array}{l}\text { Increased protection in yellowtail fish } \\
\text { against } E \text {. seriola infection. }\end{array}$ & $\begin{array}{l}\text { Edahiro et al. 1990, } \\
1991 \text { [178] [179] }\end{array}$ \\
\hline 3 & in vitro treatment with glycyrrhizin & $\begin{array}{l}\text { Enhanced respiratory burst activity of macrophages } \\
\text { and proliferative responses of lymphocytes } \\
\text { from rainbow trout. }\end{array}$ & Jang et al., 1995 [180] \\
\hline 4 & $\begin{array}{l}\text { Rainbow trout treated orally } \\
\text { with soyabean protein }\end{array}$ & $\begin{array}{l}\text { Increased leucocyte activities such as phagocytosis, } \\
\text { bacterial killing and producation of superoxide. }\end{array}$ & Rumsey et al., 1994 [181] \\
\hline 5 & $\begin{array}{l}\text { The bath administration of } \\
\text { saponin with } Y . \text { ruckeri vaccine }\end{array}$ & $\begin{array}{l}\text { Enhanced the in vitro bactericidal } \\
\text { activities in rainbow trout. }\end{array}$ & Grayson et al., 1987 [182] \\
\hline 6 & The oral administration of saponin & Increased leucocyte migration in yellowtail. & Ninomiya et al., 1995 [183] \\
\hline 7 & Immunostimulant effect of Spirulina & $\begin{array}{l}\text { Tilapia } \\
\text { Channel catfish } \\
\text { Atlantic salmon. }\end{array}$ & $\begin{array}{l}\text { Park and Jeong,1996 [184]; } \\
\text { Duncan and Klesius, } 1996 \text { [185] } \\
\text { Gildberg et al., } 1996 \text { [186] }\end{array}$ \\
\hline 8 & $\begin{array}{l}\text { Immunostimulant effect of } \\
\text { Ocimum sanctum leaf extract } \\
\text { Azadirachta indica, Piper betle, } \\
\text { Crossandra infundibuliformis } \\
\text { Sodium benzoate preserved extracts }\end{array}$ & $\begin{array}{l}\text { Enhanced antibody response to Aeromonas hydrophila. } \\
\text { Increase in antibody response and increase in } \\
\text { neutrophil activity in Oreochromis mossambicus } \\
\text { Enhanced neutrophil activity in Tilapia. }\end{array}$ & $\begin{array}{l}\text { Dinakaran, } 2001[187] \\
\text { Dinakaran, } 2001[187] \\
\text { Venkatalakshmi and } \\
\text { Dinakaran Michael, 2001 [159] }\end{array}$ \\
\hline 9 & $\begin{array}{l}\text { Acetone extract of Phyllanthus niruri, } \\
\text { Ocimum sanctum and Acalypha indica }\end{array}$ & Enhanced the antiSRBC antibody response in Tilapia. & Hemapriya, 1997 [188] \\
\hline 10 & $\begin{array}{l}\text { Catheranthus roseus, Calotropis } \\
\text { gigantea and Datura stromoneum. }\end{array}$ & Immunostimulatory effect on Cyprinus carpio. & Kiran Kumar, 2001 [171] \\
\hline 11 & Aqueous extract of neem stem bark & $\begin{array}{l}\text { Enhance immune response of } \\
\text { Balb-c mice to sheep red blood cells. }\end{array}$ & Nirjo and Kofi-Tsekpo, 1999 [44] \\
\hline 12 & Aqueous extract of neem leaf & $\begin{array}{l}\text { Potent immunostimulant activity } \\
\text { humoral and cell- both mediated responses. }\end{array}$ & $\begin{array}{l}\text { Sen et al., } 1993 \text { [163]; } \\
\text { Ray et al., } 1996 \text { [165] }\end{array}$ \\
\hline 13 & Leaf extract of neem & $\begin{array}{l}\text { Higher IgM and IgG levels along with } \\
\text { increased titer of antiovalbumin antibody. }\end{array}$ & Ray et al., 1996 [165] \\
\hline 14 & Neem oil & $\begin{array}{l}\text { Activate cell-mediated immune mechanisms } \\
\text { to elicit an enhanced response to subsequent } \\
\text { mitogenic or antigenic challenge. }\end{array}$ & Upadhyay et al., 1993 [166] \\
\hline 15 & Achyranthes aspera & $\begin{array}{l}\text { Stimulates immunity and increases } \\
\text { resistance to infection in Indian major carps. }\end{array}$ & $\begin{array}{l}\text { Chakrabarti, R. and } \\
\text { Y.V. Rao (2006). [173] }\end{array}$ \\
\hline 16 & Holy basil, Tulsi Ocimum sanctum & $\begin{array}{l}\text { Enhanced immunostimulatory action } \\
\text { in Rohu fish Labeo rohita. }\end{array}$ & Das et al., 2013 [144] \\
\hline
\end{tabular}

orchioides Gaertn.) @ 0.06 g/kg fish/day showed better growth in mrigal [191]. Kour [192] used the herb Bala (Sida cordifolia) as experimental feed and noticed significant increase in the growth of mrigal. Similarly, Singh [193] showed that growth of mrigal went up by the application of Makhana (Euryale ferox Salisb.). Similar attempts were made by [194] [195] on carps using Gokhru (Pedalium murex Linn.) and Lotus (Nelumbium speciosum Wild.) seeds respectively with encouraging results. Recently, Sharma et al. [196] showed that common carp 
(Cyprinus carpio communis L.) fed with a conventional diet (groundnut cake and rice bran@1:1) mixed with a herb Kaunch (Mucuna pruriens) seeds powder @ $0.06 \mathrm{~g} / \mathrm{kg}$ body weight/day exhibited better growth of $31.94 \%$ in comparison with control (14.28\%). The results show that these herbs could be tried as feed supplements and as nutraceuticals in commercial aquaculture; however, further works are required to know as to how these herbs help in restoring fish health.

\section{Future Research Prospects}

Medicinal plants are nature's unique gift to mankind. Recognizing the tremendous importance of herbal sector in primary health care, the World Health Organization had launched its first ever comprehensive traditional medicine strategy in 2002. The strategy is designed to assist countries to develop national policies on the evaluation and regulation of herbal practices; create a stronger evidence base on the safety, efficacy and quality of the herbal products and practices; ensure availability and affordability of phytotherapy including essential herbal medicines; promote therapeutically sound use of TM/CAM by providers and consumers; and documentation of traditional medicines and remedies.

Modern medicine faces the challenge of developing safer and more effective therapeutics. Although crude extracts from various parts of plants have been used as medicine from time immemorial, modern drugs from these extracts can be developed only after extensive investigation of their bioactive mechanisms of action, pharmacotherapeutics, toxicity, and after proper standardization in clinical trials. The bioactive natural products are important source of drug leads, but most of the times their modes of action are unknown. Thus, elucidation of their physiological targets is essential for understanding their therapeutic effects [197]. Besides, discovery of novel targets of these clinically proven compounds may also suggest new therapeutic applications. Although, considerable works have been done in the investigation of novel chemotypes and pharmacophores from many medicinal plants, but still remain a meager $5 \%$ of the total plant known to mankind, while the potential of marine and aquatic plants has barely been tapped. Very little work has been done on the biological activity and plausible medicinal application of plants in combating the numerous diseases facing the aquaculture industry. As the global scenario is now changing towards the use of nontoxic plant products, the development of modern phytochemicals and drugs from medicinal plants is the need of the time to control various fish diseases problems. Hence, more serious investigations are required to harness the therapeutic properties of medicinal plants to combat disease problems in aquaculture. Greater emphasis has to be directed towards research on herbal formulations and drug development. The fisheries fraternity has to learn a lot from the work carried out on phytotherapy of human and other animal diseases and apply the suitable principles in combating the diseases of fisheries world.

The rising commercial demand for wild-source plant drugs in many countries is occurring against a backdrop of rapid deforestation and degradation of species-rich forest ecosystems [198]. Over two-thirds of the 50,000 medicinal plants 
in use are still harvested from the wild. It is estimated that between 4000 and 10,000 of medicinal plants are now threatened or endangered. In India alone, more than 150 species have been categorized as endangered. The Convention on Biodiversity (CBD) and the Intellectual Property Rights (IPR) have laid down guidelines for the protection of a country's genetic resources. It is high time that all the stake holders related to herbal medicine production, trade and utilization must adhere to the conservation of biological diversity, the sustainable use of its components and the fair and equitable sharing of the benefits arising out of the utilization of these precious genetic resources.

An integrated approach to promote herbal medicines and medicinal plants, right from the stage of cultivation, collection, storage, processing and marketing in an organized manner with the help of leading pharmaceutical companies is needed. Systematic cultivation of medicinal herbs on a large scale by private entrepreneurs with positive support and incentives from government organizations needs to be explored.

\section{Acknowledgements}

The author is grateful to the Dr. Gopal Krishna, Director/Vice chancellor, ICAR-Central Institute of Fisheries Education, Mumbai for kind encouragements and providing necessary infrastructural facilities for carrying out the present study. The author is also thankful to Indian Council of Agricultural Research, New Delhi for financial support for the herbal project under which the present study has been carried out.

\section{References}

[1] Vaidyaratnam, P.S.V. (1995) Indian Medicinal Plants. Arya Vaidya Sala, Kottakkal. Orient Longman Ltd., Chennai.

[2] Evans, J.S., Pattison, E. and Morris, P. (1989) Antimicrobial Agents from Plants Cell Culture. In: Morris, P., Scraggs, A., Stafford, A. and Fowler, M., Eds., Secondary Metabolites in Plant Cell Culture, Cambridge University, London.

[3] Purohit, S.S. and Mathur, S.K. (1999) Drugs in Biotechnology_Fundamentals and Applications. Purohit, S.S., Ed., Maximum Publishers, India.

[4] Raman, R.P. (2001) Herbal Remedies for Finfish and Shellfish Diseases and Their Commercialization. National Seminar on Fishery Technologies and Their Commercialization, CIFE, Mumbai, 11-12 January 2001, 147.

[5] Raman, R.P. and Rahman, M.K. (2002) Phytotherapy in Fisheries. World Ayurveda Congress, Book of Abstracts, Swadeshi Science Movement and Ministry of Health and Family Welfare, Government of India, Kochi, 42.

[6] Raman, R.P., Mukherjee, S.C., Rahman, M.K. and Kamble, S. (2004) Control of Aquaculture Diseases through Traditional Medicine Systems of India. National Conference on Traditional Knowledge Systems of India, Indian Institute of Technology (IIT), Kharagpur, India, 9-11 January 2004.

[7] Raman, R.P. (2004) Preliminary Studies on Antibacterial Activity of Medicinal Plant Extracts against Some Pathogenic Bacteria of Fish. National Symposium on Disease Problems in Aquaculture-Challenges, Approaches and Management, Central Institute of Fisheries Education, Mumbai, 83. 
[8] Raman, R.P. (2007) Application of Phytotherapy in Finfish and Shellfish Health Management: A Study. In: Fisheries and Aquaculture: Strategic Outlook for Asia, $8^{\text {th }}$ Asian Fisheries Forum, Asian Fisheries Society and AFSIB, Kochi, India, 20-23 November 2007, 43.

[9] Ali, A.M., Ismail, N.H., Mackeen, M.M., Yazan, L.S., Mohamed, S.M., Ho, A.S.H. and Lajis, N.H. (2000) Antiviral, Cytotoxic and Antimicrobial Activities of Anthrquinnones Isolated from the Root of Morinda elliptica. Pharmaceutical Biology, 38, 298-301. https://doi.org/10.1076/1388-0209(200009)38:4;1-A;FT298

[10] Digrak, M., Alma, H.M., Ilcim, A. and Sen, S. (1999) Antimicrobial and Antifungal Effects of Various Commercial Plants Extract. Pharmaceutical Biology, 37, 216-220. https://doi.org/10.1076/phbi.37.3.216.6307

[11] Digrak, M., Alma, H.M., Ilcim, A. and Sen, S. (2001) Antimicrobial and Antifungal Activities of Turkish Medicinal Plants. Pharmaceutical Biology, 39, 346-350. https://doi.org/10.1076/phbi.39.5.346.5903

[12] Koneri, R., Balraman, R. and Saraswati, C.D. (2006) Antiovulatory and Abortifacient Potential of the Ethanolic Extract of Roots of Momordica cymbalaria Fenzl in Rats. Indian Journal of Pharmacology, 38, 111. https://doi.org/10.4103/0253-7613.24616

[13] Parvati, S. and Kumar, V.J. (2002) Studies on Chemical Composition and Utilization of Wild Edible Vegetable Athalakkai (Momordica tuberosa). Plant Foods for Human Nutrition, 57, 215. https://doi.org/10.1023/A:1021884406024

[14] Onajobi, F.D. (1986) Smooth Muscle Contracting Lipidic-Soluble Principles in Chromatographic Fractions of Ocimum gratissmum. Journal of Ethnopharmacology, 18, 3-11. https://doi.org/10.1016/0378-8741(86)90038-3

[15] Bhadauria, M., Jadon, A., Sharma, A. and Shukla, S. (2002) Effect of Propriety Herbal Formulation against Chronic Carbon Tetrachloride Induced Hepatotoxicity. Indian Journal of Experimental Biology, 40, 1254-1259.

[16] Aoki, T. (1992) Chemotherapy and Drug Resistance in Fish Farm in Japan. In: Shariff, M., Subasinghe, R.P. andArthur, J.P., Eds., Diseases in Asian Aquaculture, Vol. 1, Asian Fisheries Society, Manila, 519-529.

[17] Raman, R.P. and Kumar, D. (1996) An unusual Case of Drug Resistance in Aeromonas hydrophila Isolated from Bacterial Septicemia Infection in Labeo rohita in a Private Fish Farm in Andhra Pradesh. National seminar on Diseases in Aquaculture, Kakinada, Central Institute of Fisheries Education, Versova, Mumbai, 59.

[18] Mishra, P.R., Kumar, D. and Raman, R.P. (1996) Studies on Aeromonas hydrophila Induced Mortalities of Indian Major Carps in Some Carp Polyculture Farms in Orissa. National Seminar on Diseases in Aquaculture, Kakinada, Central Institute of Fisheries Education, Versova, Mumbai, India, 26.

[19] Miranda, C.D. and Zemelman, R. (2002) Antimicrobial Multiresistance in Bacteria Isolated from Freshwater Chilean Salmon Farms. The Science of the Total Environment, 293, 207-218. https://doi.org/10.1016/S0048-9697(02)00022-0

[20] Harikrishnan, R. and Balasundaram, C. (2005) Modern Trends in Aeromonas hydrophila Disease Management with Fish. Reviews in Fisheries Science, 13, 281-320. https://doi.org/10.1080/10641260500320845

[21] Harikrishnan, R. (2003) Herbal Treatment for Ulcerative Disease Induced by Aeromonas hydrophila in Goldfish (Carassius auratus). Ph.D. Thesis, Bharathidasan University, Tiruchirapalli, India.

[22] Kirtikar, K.R. and Basu, B.D. (1933) Medicinal Plants of India. Pub. L.M. Basu, Allahabad, 3. 
[23] Chopra, R.N., Nayar, S.L. and Chopra, I.C. (1956) Glossary of Indian Medicinal Plants. CSIR, New Delhi, 256.

[24] Chattopadhyay, R.R. (1991) Studies on Alcoholic Extract of Leaves of Azadirachta indica (Beng. Neem) on Carbohydrate Metabolism. Ph.D. Thesis, University of Kalyani, W.B., India.

[25] Chattopadhyay, R.R., Sarkar, S.K., Ganguli, S., Banerjee, R.N. and Basu, T.K. (1992) Hepatoprotective Activity of Azadirachta indica Leaves on Paracetamol Induced Hepatic Damage in Rats. Indian Journal of Experimental Biology, 30, 738.

[26] Chattopadhyay, R.R. (1995) Hypolipidemic Activity of Azadirachta indica Leaf Extract in Rats. Proceedings of Indian National Science Academy, B, 61, 281.

[27] Sun, X. and Wang, Y. (1992) Study on Measures for Achieving High Yield on Penaeid Shrimp (Penaeus chinensis) Culture. Oceanologia et Limnologia Sinica, 23: 454-458.

[28] Shaoqi, L. (1989) Main Diseases and Their Control. In: Integrated Fish Farming in China. NACA Technical Manual 7. A World Food Day Publication of Network Centres in Asia and the Pacific, Bangkok, Thailand, 278.

[29] Rath, R.K. (2000) Freshwater Aquaculture. 2nd Edition, Scientific Publishers, Jodhpur, India.

[30] Keshavanath, P. and Wahab, M.A. (2001) Periphyton-Based Aquaculture and Its Potential in Rural Development. Summary of an EC INCO-DC Funded Workshop. January 29-31, 2001, Ahsania Mission, Dhaka, Bangladesh. Asian Fisheries Society, Indian Branch, Mangalore, India.

[31] Azim, M.E., Verdegem, M.C.J., Wahab, M.A., van Dam, A.A. and Beveridge, M.C.M. (2001) Periphyton Boosts Production in Pond Aquaculture Systems. World Aquaculture Society, 32, 57-61.

[32] Wahab, M.A., Azim, M.E., Verdegem, M.C.J., van Dam, A.A. and Beveridge, M.C.M. (2001) Periphyton-Based Aquaculture: Potentials and Constraints. In: Shankar, K.M. amd Mohan, C.V., Eds., Potential of Artificial Substrate Based Microbial Biofilm in Aquaculture. National Workshop Manual. UNESCO Sponsored Workshop, Mangalore, 15-16 October 2001, 45-59.

[33] Dey, R.K. and Chandra, S. (1994) New Trends in Fish Disease Management through Application of Herbal Material. Fishing Chimes, 14, 13-14.

[34] Dey, R.K. and Chandra, S. (1995) Preliminary Studies to raise Disease Resistant Seed (Fry) through Herbal Treatment of Spawn. Fishing Chimes, 14, 23-25.

[35] Hota, S.K. and Dey, R.K. (1997) Studies on the in Vitro Effect of Turmeric on Some Fish Pathogenic Bacteria. Fishing Chimes, 17, 9-10.

[36] Yusuf, N.A., Ibrahim, H. and Khalid, N. (2001) Antibacterial Evaluation and Tissue Culture Studies of Selected Medicinal Curcuma Species. National Science Foundation Workshop, Kuala Lumpur, Malaysia.

[37] Kikuzaki, H., Kawasaki, Y. and Nakatani, N. (1994) Structure of Antioxidative Compounds in Ginger. In: Food Phytochemicals for Cancer Prevention II, American Chemical Society Symposium Series No. 547, 237-243. https://doi.org/10.1021/bk-1994-0547.ch024

[38] Masuda, T. and Jitoe, A. (1994) Antioxidative and Anti-Inflammatory Compounds from Tropical Gingers; Isolations, Structure Determination and Activities of Cassumins A, B and C, New Complex Cucumioids from Gingiber cassimunar. Journal of Agricultural and Food Chemistry, 23, 128-131.

[39] Baruah, P. and Sarma, G.C. (1987) Studies on the Medicinal Uses of Plants by the North-East Tribes-III. Ibid, 11, 71-76. 
[40] Chopra, I.C., Gupta, K.C. and Nazir, B.N. (1952) Preliminary Study of Anti-Bacterial Substances from Melia azidirachta. Indian Journal of Medical Research, 40, 511-515.

[41] Patel, R.P. and Trivedi, B.M. (1962) The In Vitro Antibacterial Activity of Some Medicinal Oils. Indian Journal of Medical Research, 50, 218-222.

[42] Satyavati, G.V., Raina, M.K. and Sharma, M.K. (1976) Medicinal Plants of India, ICAR, New Delhi.

[43] Ahmad, I., Ahmad, F. and Hussain, S. (1995) In Vitro Antimicrobial Activity of Leaf and Bark Extracts of Azadiracta indica Juss. Indian Veterinary Medical Journal, 19, 204-206.

[44] Njiro, S.M. and Kofi-Tsekpo, M.W. (1999) Effect of an Aqueous Extract of Azadirachta indica on the Immune Response in Mice. Onderstepoort Journal of Veterinary Research, 66, 59-62.

[45] Murty, S.P. and Sirsi, M. (1958) Journal of Physiology and Pharmacology, 2, 458.

[46] Mitra, C.R., Garg, H.S. and Pandey, G.N. (1971) Constituents of Azadirachta indica 3. Identification of Nimbidic Acid and Nimbidinin from Azadirachta indica. Phytochemistry, 10, 857-864. https://doi.org/10.1016/S0031-9422(00)97156-5

[47] Rochanakij, S., Thebtaranonth, Y.C., Yenjal, H. and Yuthabong, H. (1985) Nimbolide, a Constituent of Azadirachta indica, Inhibits Plasmodium falciparum in Culture. The Southeast Asian Journal of Tropical Medicine and Public Health, 16, 6672.

[48] Khalid, S.A., Duddeck, H. and Gonzalez, S.M. (1989) Isolation and Characterization of an Antimalarial Agent of the Neem Tree Azadirachta indica. Journal of Natural Products, 52, 922-927. https://doi.org/10.1021/np50065a002

[49] Devakumar, C. and Sukhdev, S. (1996) In: Randhawa and Parmar, B.S., Eds., Neem, 2nd Edition, Society of Pesticide Science, New Delhi, 77-110.

[50] Ara, I., Siddiqui, B.S., Faizi, S. and Siddiqui, S. (1989) Structurally Novel Diterpenoid Constituents from the Stem Bark of Azadirachta indica (Meliaceae). Journal of the Chemical Society, Perkin Transactions, 1, 343-345.

https://doi.org/10.1039/p19890000343

[51] Das, B.K., Mukherjee, S.C., Sahu, B.B. and Murjani, G. (1999) Neem (Azadirachta indica) Extract as an Antibacterial Agent against Fish Pathogenic Bacteria. Indian Journal of Experimental Biology, 37, 1097-1100.

[52] Sahu, B.B., Mukherjee, S.C., Das, B.K. and Murjani, G. (1996) Aquaneem-An Effective Bactericide. In: National Seminar on Diseases in Aquaculture, CIFE, Kakinada, 33 .

[53] Citarasu, T., Babu, M.M., Babu, S.M., Punitha, J., Ramalingam, V. and Marian, M.P. (2001) Control of Pathogenic Bacteria Using Herbal Biomedical Products in the Larviculture System of Penaeus monodon. Int. Con. Ad. Tech. Fish Mar. Sci., Indian Council of Agricultural Science, M.S. University, Nagercoil, India.

[54] Xu, B., Ji, W., Zhang, P., Xu, H. and Shi, J. (1993) Comparision of Antibacterial Agents for Control of Pathogen in Culture Shrimp Penaeus orientalis. Journal of Ocean University of China, 23, 43-57.

[55] Jin, S., Wang, G.L., Zhao, Q.S. and Chen, H.Q. (2000) Medical Study on Provenion and Cure for Skin Ulcer Disease of Marine Cage-Cultured Sea-Perch. Journal of Oceanography in Taiwan Strait, 2000-02.

[56] Sun, D., Chen, Y. and Zhou, H. (2005) Control of the Bacterial Gill Rot Found in Fat Greenling Hexagrammos otakii by Chinese Herbal Medicines. Fisheries Science/ Shuichan Kexue, 24, 30-31. 
[57] Shuming, Z., Yong, Z., Liyi, W. and Yingle, Z. (2006) Prevention of the Bacterial Septicemia of Carassius auratus auratus by Chinese Herbal Compound and the Infection on Its Immunity. Journal of Dalian Fisheries University/Dalian Shuichan Xueyuan Xuebao, 21, 31-36.

[58] Zheng, T.L., Wang, G.L. and Jin, S. (2005) Administration of Chinese Herbal Medicines in Control of Vibriosis in Cage-Cultured Large Yellow Croaker. Fisheries Science/Shuichan Kexue, 24, 24-25.

[59] Janssen, A.M., Scheffer, J.J., Ntezurubanza, L. and Svendsen, A.B. (1989) Antimicrobial Activities of Some Ocimum Species Grown in Rwanda. Journal of Ethnopharmacology, 26, 57-63. https://doi.org/10.1016/0378-8741(89)90113-X

[60] Bhargava, K.P. and Singh, N. (1981) Anti-Stress Activity of Ocimum sanctum Linn. Indian Journal of Medical Research, 73, 443-451.

[61] Day, B.B. and Choudhury, M.A. (1981) Essetial Oil of Ocimum sanctum L. and Its Antimicrobial Activity. Indian Perfum, 28, 82-87.

[62] Immanuel, G., Vincybai, V. C., Sivaram, V., Palavesam, A. and Marian, M.P. (2004) Effect of Butanolic Extracts from Terrestrial Herbs and Seaweeds on the Survival, Growth and Pathogen (Vibrio parahaemolyticus) Load on Shrimp Penaeus indicus juveniles. Aquaculture, 236, 53-65.

https://doi.org/10.1016/j.aquaculture.2003.11.033

[63] Bhuvaneswari, R. and Balasundaram, C. (2006) Traditional Indian Herbal Extracts Used in Vitro against Growth of the Pathogenic Bacteria-Aeromonas hydrophila. Israeli Journal of Aquaculture/Bamidgeh, 58, 89-96.

[64] Chakraborty, K., Lipton, A.P. and Paul Raj, R. (2007) New Antibacterial Compounds from Ulva fasciata (Gray). Mar. Fish. Infor. Serv., T \& E Ser., 194, 11-12.

[65] Srivastava, M. (1996) In Vitro Antimicrobial Studies of the Essential Oil of Vitis adnata. Asian Journal of Chemistry, 8, 810.

[66] Syed, M., Qamar, S., Riaz, M. and Chaudhary, F.M. (1995) Essential Oils of the Family Gramineae with Antibacterial Activity. Part 2: The Antibacterial Activity of a Local Variety of Cymbopogon citratus Oil and its Dependence on the Duration of Storage. Pakistan Journal of Scientific and Industrial Research, 38, 146-148.

[67] Vijaya, K. and Ananthan, S. (1996) Therapeutic Efficacy of Medicinal Plants against Experimentally Induced Shigellosis in Guinea pigs. Indian Journal of Pharmaceutical Sciences, 58, 191-193.

[68] Chowdhury, A.K.A., Ali, M.S. and Khan, M.O. (1997) Fitoterapia, 68, 379-38.

[69] Kyung, K.H. and Fleming, H.P. (1997) Antimicrobial Activity of Sulfur Compounds Derived from Cabbage. Journal of Food Protection, 60, 67-71. https://doi.org/10.4315/0362-028X-60.1.67

[70] Sathawane, P.N., Patel, D.L., Kasture, V.S., Kasture, S.B. and Pal, S.C. (1997) Antimicrobial Activity of Extracts of Anacardium occidentale. Indian Drugs, 34, 459462.

[71] Kulkarani, C.G., Ravetkar, S.D. and Kulkarni, P.N. (1995) Antibacterial Properties of Ayurvedic Prepartions "Bhallatakasava" and "Sukshma Triphala". Deerghayu International, 11, 3-5.

[72] Leite, C.Q.F., Moreira, R.R.D. and Neto, J.J. (1998) Action of Eucalyptus Oil against Mycobacterium avium. Fitoterapia, 69, 282-283.

[73] Srivastava, R., et al. (1997) Antibacterial Activity of Centella asiatica. Fitoterapia, 68, 466-467.

[74] Valsaraj, R., Pushpangadan, P., Smitt, U.W., Adsersen, A. and Nyman, U. (1997) 
Antimicrobial Screening of Selected Medicinal Plants from India. Journal of Ethnopharmacology, 58, 75-83. https://doi.org/10.1016/s0378-8741(97)00085-8

[75] Subashini, R., Manimaran, S. and Ruckmani, K. (2000) Antimicrobial Activity of Leaf Extraction of Gloriosa superba Linn. Proceedings of International Congress on Ayurveda -2000, 216.

[76] Tambekar, D.H. and Dahikar, S.B. (2011) Antibacterial Activity of Some Indian Ayurvedic Preparations against Enteric Bacterial Pathogens. Journal of Advanced Pharmaceutical Technology \& Research, 2, 24-29. https://doi.org/10.4103/2231-4040.79801

[77] Pal, S.K., Mukherjee, P.K. and Saha, B.P. (1995) Studies on the Antiulcer Activity of M. oleifera leaf Extract on Gastric Ulcer Models in Rats. Phytotherapy Research, 9, 463-465.

[78] Jain. S.C., Sharma, R., Kain, R. and Sharma, R.A. (1996) Antimicorbcorbial Activity of Calotropis procera. Fitoterapia, 67, 275-277.

[79] Sahu, S., Das, B.K., Mishra, B.K., Pradhan, J. amd Sarangi, N. (2007a) Effect of Allium sativum on the Immunity and Survival of Labeo rohita Infected with Aeromonas hydrophila; Journal of Applied Ichthyology, 23, 80-86. https://doi.org/10.1111/j.1439-0426.2006.00785.x

[80] Sahu, S., Das, B.K., Pradhan, J., Mohapatra, B.C., Mishra, B.K. and Sarangi, N. (2007b) Effect of Magnifera indica Kernel as a Feed Additive on Immunity and Resistance to Aeromonas hydrophila in Labeo rohita Fingerlings. Fish \& Shellfish Immunology, 23, 109-118. https://doi.org/10.1016/j.fsi.2006.09.009

[81] Kumar, S., Raman, R.P., Kumar, K., Pandey, P.K., Kumar, N., Mohanty, S. and Kumar, A. (2012a) In Vitro and in Vivo Antiparasitic Activity of Azadirachtin against Argulus spp. in Carassius auratus (Linn. 1758). Parasitology Research, 110, 17951800. https://doi.org/10.1007/s00436-011-2701-0

[82] Kumar, S., Raman, R.P., Kumar, K., Pandey, P.K., Kumar, N., Mallesh, B., Mohanty, S. and Kumar, A. (2012b) Effect of Azadirachtin on Haematological and Biochemical Parameters of Argulus-Infested Goldfish Carassius auratus (Linn. 1758). Fish Physiology and Biochemistry, 39, 733-747. https://doi.org/10.1007/s10695-012-9736-8

[83] Kumar, S., Raman, R.P., Pandey, P.K., Mohanty, S., Kumar, A. and Kumar, K. (2013) Effect of Orally Administered Azadirachtin on Non-Specific Immune Parameters of Goldfish Carassius auratus (Linn. 1758) and Resistance against Aeromonas hydrophila. Fish \& Shellfish Immunology, 34, 564-573. https://doi.org/10.1016/j.fsi.2012.11.038

[84] Rao, P.V.S.V.P. (1996) Rise and Reduction of White Spot Disease among Shrimp under Culture in Andhra Pradesh-Prevention and Cure. Fishing Chimes, 16, 9-11.

[85] Mukherjee, S.C. (1996) Training Programme on Fish Diseases, Their Diagnosis and Control. Central Institute of Freshwater Aquaculture (ICAR), Bhubaneswar, India.

[86] Citarasu, T., Sivaram, V., Immanuel, G., Rout, N. and Murugan, V. (2006) Influence of Selected Indian Immunostimulant Herbs against White Spot Syndrome Virus (WSSV) Infection in Black Tiger Shrimp, Penaeus monodon with Reference to Haematological, Biochemical and Immunological Changes. Fish \& Shellfish Immunology, 21, 372-384. https://doi.org/10.1016/j.fsi.2006.01.002

[87] Rao, A.R., Kumar, S., Paramsivam, T.B., Kamalakshi, S., Parashuram, A.R. and Shantha, M. (1969) Study of Antiviral Activity of Tender Leaves of Margosa Tree (Melia azadirachta) on Vaccinia and Variola Virus: A Preliminary Report. Indian Journal of Medical Research, 57, 495-502. 
[88] Gogati, S.S. and Marathe, A.D. (1989) Anti-Viral Effect of Neem Leaf (Azadirachta indica) Extracts on Chinkugunga and Measles Viruses. Journal of Research and Education in Indian Medicine, 8, 1-5.

[89] Badam, L., Joshi, S.P. and Bedekar, S.S. (1999) “In Vitro" Antiviral Activity of Neem (Azadirachta indica. A. Juss) Leaf Extract against Group B Coxsackie Viruses. Journal of Communication Disorders, 31, 79-90.

[90] Bunyapraphatsara, N., Dechsree, S., Yoosook, C., Herusalee, A. and Panpisutchai, Y. (1999) Anti-Herpes Simplex Virus Component Isolated from Maclura cochinchinensis. Phytomedicine, 6, 421-424. https://doi.org/10.1016/S0944-7113(00)80069-0

[91] Yoosook, C., Bunyapraphatsara, N., Bunijakiat, Y. and Kantasuk, C. (1999) AntiHerpes Simplex Virus Activities of Crude Water Extract of Thai Medicinal Plants. Phytomedicine, 6, 411-419. https://doi.org/10.1016/S0944-7113(00)80068-9

[92] Badam, L. (1995) In Vitro Studies on the Effects of Acorus calamus Extract and Beta-Asarone on Herpes Viruses. Deerghayu International, 11, 16-18.

[93] Chandra, K., Gupta, P., Singh, K.L. and Tandon, J.S. (1998) Antiviral Activity of an Extract of Syzygium megacarpum against Encephalitis Causing Virus. Indian Jounral of Virology, 14, 31-35.

[94] Rana, N.S. and Joshi, M.N. (1998) Antiviral Activity of Some Indian Plants. Indian Journal of Virology, 14, 47-49.

[95] Serkedjieva, J. (1996) A Polyphenolic Extract from Geranium sanguineum L. Inhibits Influenza Virus Protein Expression. Phytotherapy Research, 10, 441-443. https://doi.org/10.1002/(SICI)1099-1573(199608)10:5<441::AID-PTR867>3.0.CO;2-9

[96] Saxena, G., Gupta, P., Chandra, K. and Lakshmi, V. (1997) Antiviral Activity of Hyptianthera stricta L. against encephalitis Causing Viruses. Indian Drugs, 34, 694 698.

[97] Chakraborty, S. and Ghosh, U. (2013) Comparative Study of in Vivo Metabolic Parameters in WSSV Infected Litopenaeus vannamei, Treated with Anti-WSSV Drug Derived from Marine and Terrestrial Plants. International Journal of Toxicology and Applied Pharmacology, 3, 58-72.

[98] Ghosh, U. and Chakraborty, S. (2013) In Vivo Immunological Changes Occurring at Different Time Intervals in White Spot Syndrome Virus Infected Shrimp, Treated with Anti-WSSV Drug Derived from Terrestrial Plants. International Journal of Microbiology and Immunology Research, 2, 70-86.

[99] Auro-de-Ocampo, A. and Jimenez, E.M. (1993) Herbal Medicines in the Treatment of Fish Diseases in Mexico. Veterinaria México, 24, 291-295.

[100] Khan, M. and Wassilew, S.W. (1987) In: Schmutterer, H. and Asher, K.R.S., Eds., Natural Pesticides from the Neem Tree and Other Tropical Plants, GTZ, Eschborn, 645-650.

[101] Biswas, K., Chattopadhyay, I., Banerjee, R.K. and Bandopadhyay, U. (2002) Biological Activities and Medicinal Properties of Neem (Azadiracta indica). Current Science, 82, 1336-1345.

[102] Govindachari, T.R., Suresh, G. and Masilamani, S. (1999) Antifungal Activity of Azadirachta indica leaf Hexane Extract. Fitoterapia, 70, 417-420. https://doi.org/10.1016/S0367-326X(99)00038-6

[103] Murthy, S.P. and Sirsi, M. (1958) Chemical Properties of Neem-A. juss. Indian journal of physiology and pharmacology, 2, 387-396.

[104] Rao, B.S., Nazma and Rao, J.M. (1977) Current Science, 46, 714- 716.

[105] Pant, N., Garg, H.S., Madhusudanan, K.P. and Bhakuni, D.S. (1986) Sulfurous 
Compounds from Azadirachta indica Leaves. Fitoterapia, 57, 302-304.

[106] Goswami, B., Mondal, S. and Dana, S.S. (2006) Indigenous Technical Knowledge in Fish Farming. Indian Journal of Traditional Knowledge, 5, 60-63.

[107] Apisariyakul, A., Vanittanakom and Buddhasukh, D. (1995) Antifungal Activity of Turmeric Oil Extracted from Curcuma longa (Zingiberaceae). Journal of Ethnopharmacology, 49, 163-169. https://doi.org/10.1016/0378-8741(95)01320-2

[108] Kishore, N., Chansoria, J.P.N. and Dubey, N.K. (1996) Antidermatophytic Action of the Essential Oil of Chenopodium ambrosioides and an Ointment Prepared from It. Phytotherapy Research, 10, 453-455. https://doi.org/10.1002/(SICI)1099-1573(199608)10:5<453::AID-PTR874>3.0.CO;2-A

[109] Alice, D. and Sivaprakasam, K. (1999) Fungicidal, Bactericidal and Nematicidal Effect of Garlic Clove Extract. Journal of Ecobiology, 8, 99-103.

[110] Sharma, R.N. and Saxena, V.K. (1996) In Vitro Antimicrobial Activity of Leaves Extracts of Bauhinia variegata. Asian Journal of Chemistry, 8, 811-812.

[111] Mukherjee, P.K., Saha, K., Giri, S.N., Pal, M. and Saha, B.P. (1995) Antifungal Screening of Nelumbo nucifera (Nymphaeceae) Rhizome Extract. India Journal of Microbiology, 35, 327-330.

[112] Shahi, S.K., Shukla, A.C. and Dikshit, A. (1999) Antifungal Studies of Some Essential Oils at Various pH Levels for Betterment of Antifungal Drug Response. Current Science, 77, 703-706.

[113] Mishra, S.P., Mishra, M. and Tewari, S.N. (1997) Ecalyptus citridora, a Potential Fungicidal Source for Rice Blast Control. Abstracts of Papers. International Conference of Integrated Plant Disease Management, New Delhi, 10-15 November 1997, $10-15$.

[114] Oketch-Rabah, H.A., Dossaji, S.F., Christensen, S.B., Frydenvang, K., Lemmich, E., Cornett, C., Olsen, C.E., Chen, M., Kharazm, A. and Theander, T. (1997) Antiprotozoal Compounds from Asparagus africanus. Journal of Natural Products, 60, 1017-1022. https://doi.org/10.1021/np970217f

[115] Mitchell, A.J. and Hoffman, G.L. (1980) Important Tapeworms of North American Freshwater Fishes-Fish Disease Leaflet. Sr. No. 59, U.S. Fish and Wildlife Service, $18 \mathrm{p}$.

[116] Post, G. (1987) Textbook of Fish Health. T. F. H. Publication, Inc., USA, 288.

[117] Neeraja, B. and Narayana, G. (1998) Use of Neemol for Cestode Infected White Leghorns to Increase Egg Production. Geobios, 25, 149-151.

[118] Jangde, C.R., Maske, D.K., Srikhande, G.B., Sirothia, A.R. and Sirothia, K.A. (2001) In Vitro Antihelminthic acTivity of Artemesia maritima and Butea frondosa against Haemonchus controlus in Bullock. Indian Veterinary Journal, 78, 295-297.

[119] Rajasekaran, M., et al. (1989) J. Drug Dev, 2, 179-182.

[120] Tiwari, B.N., Singh, K.P., Patra, P.K., Das, P.B. and Narain, R. (2006) Use of Square Banana Stem Technique for Control of aquatic Insects in Nursery Ponds (Abstract in Hindi). National Seminar on Fisheries of North-Eastern States, India, 6 December 2006, 84.

[121] Vietmeyer, N.D. (1992) Neem: A Tree for Solving Global Problems. National Academy Press, Washington DC, 1-141.

[122] Srinivasan, G., Babu P.C., Sundara and Murugeswari, V. (2001) Effect of Neem Products and Insecticides on the Egg Parasitoids, Trichogramma spp. (Trichogrammatidae: Hymenoptera). Pesticide Research Journal, 13, 250-253.

[123] Paruthi, I.J., Kanwar, R.S. and Gupta. D.C. (1996) In Vitro Evaluation of Achook-A 
Neem Based Pesticide against Root-Knot Nematode, Meloidogyne incognita. Indian Journal of Nematology, 26, 270- 272.

[124] Singh, S., Majumdar, D.K. and Yadav, M.R. (1996) Chemical and Pharmacological Studies on Fixed Oil of O. sanctum. Indian Journal of Experimental Biology, 34, 1212-1215.

[125] Kumar, A., Raman, R.P., Kumar, K., Pandey, P.K., Kumar, V., Mohanty, S. and Kumar, S. (2012) Antiparasitic Efficacy of Piperine against Argulus spp. on Carassius auratus (Linn. 1758): In Vitro and In Vivo Study, Parasitology Research, 111, 2071-2076. https://doi.org/10.1007/s00436-012-3054-Z

[126] Osuala, F.O. and Okwuosa, V.N. (1993) Toxicity of Azadirachta indica to Freshwater Snails and Fish, with Reference to the Physicochemical Factor Effect on Potency. Applied Parasitology, 34, 63-68.

[127] Bail, H.S., Singh, S. and Patil, Y. (1985) Preliminary Screening of Some Plants for Molluscicidal Activity against Two Snail Species. Indian Journal of Animal Sciences, 55, 338-340.

[128] Dimetry, N.Z. and El-Hawary, F.M.A. (1995) Neem Azal-F as an Inhibitor of Growth and Reproduction in the Cowpea Aphid Aphis craccivora Koch. Journal of Applied Entomology, 119, 67-71. https://doi.org/10.1111/j.1439-0418.1995.tb01245.x

[129] Gnanapragasam, W.C., Mohotti, M., Sureshkumar, B. and Udamulla, G.P. (1993) Effect of "Jawan" a Neem Based Natural Pesticide in Controlling Nematode Pests of Tea. Sri Lanka Journal of Tea Science, 62, 47-52.

[130] Gangopadhyay, S. (1995) Use of Curcuma longa and Azadirachta indica for Safe Storage of Foodgrains. International Conference on Current Progress in Medicinal and Aromatic Plant Research, Calcutta, 30 December 1994-1 January 1995, 99.

[131] El-shazly, M.M. and El-sharnoubi, E.D. (2000) Toxicity of a Neem (Azadirachta indica) Insecticide to Certain Aquatic Organisms. Journal of the Egyptian Society of Parasitology, 30, 221-231.

[132] Singh, K., Singh, A. and Singh, D.K. (1996) Molluscicidal Activity of Neem (Azadirachta indica A. Juss.). Journal of Ethnopharmacology, 52, 35-40. https://doi.org/10.1016/0378-8741(96)01383-9

[133] Medda, C., Bhattacharya, B., Sarkar, S.K., Ganguli, S. and Basu, T.K. (1995) Effect of Rotenone on Activity of Some Enzymes and Their Recovery in Freshwater Carp Fingerlings of Labeo rohita. Journal of Environmental Biology, 16, 55-60.

[134] Babu, N. (1965) Observations on the Toxicity of the Seeds of Croton tiglium Linn. on Predatory Weed Fishes. Science \& Culture, 31, 308-310.

[135] Bhuyan, B.R. (1968) A Note on the Use of Croton tiglium Linn. Seed as Fish Poison in Ponds. Journal of Bombay Natural History Society, 65, 236-240.

[136] Ohta, K., Cen, Y., Maruma, S. and Manakata, K. (1969) Studies on the Piscicidal Components of Justicia hayati var. Decumbens Part 1. Isolation and Piscicidal Activities of Justcidin A and B. Agricultural and Biological Chemistry, 33, 610-614.

[137] Chakraborty, D.P., Nandy, A.C. and Philipose, M.T. (1972). Barringtonia acutangula (L.) Gaertn as Fish Poison. Indian Journal of Experimental Biology, 10, 78-80.

[138] Nandy, A.C. and Chakraborty, D.P. (1976) A Note on the Use of Unripe Fruits of Randia dumetorum Lam. as a Fish Poison. Journal of the Inland Fisheries Society of India, 8, 134-136.

[139] Kanasaki, T. and Ohta, K. (1976) Isolation and Identification of Costunolide as a Piscicidal Component of Marchantia polymorpha. Agricultural and Biological Chemistry, 40, 1239. https://doi.org/10.1080/00021369.1976.10862197 
[140] Ramanujam, S.N. and Ratha, B.K. (1968) Studies on Piscicidal Plants of North Eastern India: Hope for an Indigenous Plant Poison for Fish Nursery Management. Current Science, 49, 251-252.

[141] Bhatia, H.L. (1970) Use of Mahua Oil Cake in Fishery Management. Indian Farming, 20, 39-40.

[142] Anderson, D.P. (1992) Immunostimulants, Adjuvants and Vaccine Carriers in Fish: Applications to Aquaculture. Annual Review of Fish Diseases, 2, 281-307. https://doi.org/10.1016/0959-8030(92)90067-8

[143] Saurav, K., Raman, R.P., Pandey, P.K., Mohanty, S., Kumar, A. and Kumar, K. (2013) Effect of Orally Administered Azadirachtin on Non-Specific Immune Parameters of Goldfish Carassius auratus (Linn. 1758) and Resistance against Aeromonas Hydrophila. Fish \& Shellfish Immunology, 34, 564-573. https://doi.org/10.1016/j.fsi.2012.11.038

[144] Das, R., Raman, R.P., Saha, H. and Singh, R. (2015) Effect of Ocimum sanctum Linn. (Tulsi) Extract on the Immunity and Survival of Labeo rohita (Hamilton) Infected with Aeromonas hydrophila. Aquaculture Research, 46, 1111-1121. https://doi.org/10.1111/are.12264

[145] Hadden, J.W. (1993) Immunostimulants. Immunology Today, 14, 275-282. https://doi.org/10.1016/0167-5699(93)90045-M

[146] Wagner, H. and Prokash, A. (1985) Immunostimulatory Drugs of Fungi and Higher Plants. In: Wagner, H., Ed., Economic and Medicinal Plant Research, Vol. I, Academic Press, London, New York, 113.

[147] Wagner, H. (1996) Herbal Immunostimulants. Zeitschrift für Phytotherapie, 17, 79-95.

[148] Wagner, H. (1996) Plant Drug Analysis. Bladt, S., Ed., 2nd Edition, Springer Verlag, Berlin, Heidelburg, New York, 3-6. https://doi.org/10.1007/978-3-642-00574-9

[149] Agarwal, S.S. and Singh, V.K. (1999) Immunomodulators Studies on Indian Medicinal Plants and Synthetic Part 1: Medicinal Plants. Proceedings of the National Academy of Sciences, 65, 179-204.

[150] Bafna, A.R. and Mishra, S.H. (2004) Immunomodulatory Activity of Methanol Extract of Flower-Heads of Sphaeranthus indicus Linn. ARS Pharmaceutica, 45, 281.

[151] Campbell, R.E., Lilley, J.H. and Richards, R.H. (1998) The Use of Natural Products in the Treatment of EUS (Epizootic Ulcerative Syndrome). In: Kane, A.S. and Poynton, S.L., Eds., Proceedings of the International Symposium on Aquatic Animal Health, Baltimore, 114.

[152] Chakraborty, C. and Chattopadhyay, A.K. (1998) Turmeric (Curcuma longa) and Neem Leaf (Azadirachta indica) Extract in the Management of Bacterial Infection in African Catfish. Clarius gariepinus (Burchell). Fishing Chimes, 18, 17.

[153] Dinakaran Michael, R. (2001) Scope for Using Medicinal Plant Extracts as Immunostimulants in Finfish Aquaculture. National Workshop on Aquaculture Medicine, 81-82.

[154] Yuan, C.T., Li, D.M., Chen, W., Sun, F.F., Wu, G.H., Gong, Y., Tang, J.Q., Shen, M.F. amd Han, X.D. (2007) Administration of a Herbal Immunoregulation Mixture Enhances Some Immune Parameters in Carp (Cyprinus carpio). Fish Physiology and Biochemistry, 33, 93-101. https://doi.org/10.1007/s10695-006-9120-7

[155] Ardo, L., Yin, G., Xu, P., Varadi, L., Szigeti, G., Jeney, Z. and Jeney, G. (2008) Chinese Herbs (Astragalus membranaceus and Lonicera japonica) and Boron Enhance the Non-Specific Immune Response of Nile Tilapia (Oreochromis niloticus) and Resistance against Aeromonas hydrophila. Aquaculture, 275, 26-33. 
https://doi.org/10.1016/j.aquaculture.2007.12.022

[156] Seung-Cheol, J., Osamu, T., Gwan-Sik, J., Lee, S.-W., Ishimaru, K., Seoka, M. and Kenji, T. (2007) Dietary Medicinal Herbs Improve Growth and Some Non-Specific Immunity of Red Sea Bream Pagrus major. Fisheries Science, 73, 63-69. https://doi.org/10.1111/j.1444-2906.2007.01302.x

[157] Singh, S. and Majumdar, D.K. (1997) Evaluation of Anti-Inflammatory Activity of Fatty Acids of O. sanctum Fixed Oil. Indian Journal of Experimental Biology, 35, 380-383.

[158] Agarwal, K.C. (1996) Therapeutic Actions of Garlic Constituents. Medicinal Research Reviews, 16, 111-124. https://doi.org/10.1002/(SICI)1098-1128(199601)16:1<111::AID-MED4>3.0.CO;2-5

[159] Venkatalakshmi, S. and Michael, R.D. (2001) Immunostimulation by Leaf Extract of Ocimum sanctum Linn. in Oreochromis mossambicus (Peters). Journal of Aquaculture in the Tropics, 16: 1-10.

[160] Venkatesan, P., Devasree, L.D. and Michael, R.D. (2001) Immunostimulatory Effect of Ocimum sanctum Leaf Extract Administered by Immersion in Oreochromis mossambicus. National Workshop on Aquaculture Medicine, Kochi, India, 88.

[161] Ruby, A.J., Kuttan, G., Babu, K.D., Rajasekharan, K.N. and Kultan, R. (1995) Anti-Tumour and Antioxidant Activity of Natural Curcuminoids. Cancer Letters, 109, 79. https://doi.org/10.1016/0304-3835(95)03827-J

[162] Selvam, R., Subramanian, I., Gayathri, R. and Angayarkanni, N. (1995) The Antioxidant Activity of Turmeric (Curcuma longa). Journal of Ethnopharmacology, 47, 59. https://doi.org/10.1016/0378-8741(95)01250-H

[163] Sen, P., Medirapta, P.K., Ray, A. and Puri, S. (1993) An Experimental Evaluation of Azadirachta indica in Normal Stressed Rats and Adaptogenic Effect. Chary, M.S., Singh, R.P., Kraus, W. and Saxena, R.C., Eds., World Neem Conference, Oxford and Indian Book House Publications Pvt. Ltd., London.

[164] Wali, N., Dharan, S., Garg, S. and Upadhyay, S.N. (1993) Anti-inflammatory Effect of Extract of Neem Leaf. Chary, M.S., Singh, R.P., Kraus, W. and Sxena, R.C., Eds., World Neem Conference, Oxford and Indian Book House Publications Pvt. Ltd., London.

[165] Ray, A., Banerjee, B.D. and Sen, P. (1996) Modulation of Humoral and Cell Mediated Immune Reponses by Azadirachta indica (Neem) in Mice. Indian Journal of Experimental Biology, 34, 698-701.

[166] Upadhyay, N., Dhawan, S., Garg, S., Wali, N., Turker, L. and Anderson, D.J. (1993) Immunomodulatory Properties of Neem (Azadirachta indica). Chary, M.S., Singh, R.P., Kraus, W. and Sxena, R.C., Eds., World Neem Conference, Oxford and Indian Book House Publications Pvt. Ltd., London.

[167] Sadekar, R.D., Kolte, A.Y., Barmase, B.S. and Desai, V.P. (1998) Immunopotentiating Effects of Azadirachta indica (Neem) Dry Leaves Powder in Broilers, Naturally Infected with IBD Virus. Indian Journal of Experimental Biology, 36, 1151-1153.

[168] Logambal, S.M. and Michael, R.D. (2001) Azadirachtin-An Immunostimulant for Oreochromis mossambicus (Peters). Journal of Aquaculture in the Tropics, 16, 339347.

[169] Sen, P., Medirapta, P.K. and Ray, A. (1992) Immunostimulant Activities of $A$. indica. Indian Journal of Experimental Biology, 12, 1170-1175.

[170] Upadhyay, S.N., Dhawan, S., Garg, S. and Talwar, G.P. (1992) Immunomodulatory Effects of Neem (Azadirachta indica) Oil. International Journal of Immunopharmacology, 14, 1187-1193. https://doi.org/10.1016/0192-0561(92)90054-O 
[171] Kiran Kumar, N. (2001) Effect of Certain Plant Extracts on Immune System of $C y$ prinus carpio. M.F.Sc. Dissertation, CIFE, Mumbai, India.

[172] Rao, Y.V. and Chakrabarti, R. (2005) Stimulation of Immunity in Indian Major Carp Catla catla with Herbal Feed Ingredients. Fish \& Shellfish Immunology, 18, 327-334. https://doi.org/10.1016/j.fsi.2004.08.005

[173] Chakrabarti, R. and Rao, Y.V. (2006) Achyranthes aspera Stimulates the Immunity and Enhances the Antigen Clearance in Catla catla. International Immunopharmacology, 6, 782-790. https://doi.org/10.1016/j.intimp.2005.11.020

[174] Rao, Y.V., Romesh, M., Singh, A. and Chakrabarti, R. (2004) Potentiation of Antibody Production in Indian Major Carp Labeo rohita, Rohu, by Achyranthes aspera as a Herbal Feed Ingredient. Aquaculture, 238, 67-73. https://doi.org/10.1016/j.aquaculture.2004.04.029

[175] Rao, Y.V., Das, B.K., Jyotirmayee P. and Chakrabarti, R. (2006) Effect of Achyranthes aspera on the Immunity and Survival of Labeo rohita Infected with Aeromonas hydrophila. Fish and Shellfish Immunology, 20, 263-273. https://doi.org/10.1016/j.fsi.2005.04.006

[176] Siwicki, A.K., Anderson, D.P. and Rumsey, G.L. (1994) Dietary Intake of Immunoistimulants by Rainbow Trout Affects Non-Specific Immunity and Protection against Furunculosis. Veterinary Immunology and Immunopathology, 34: 379-389.

[177] Wada, T., Arima, T. and Nagashima, H. (1987) Natural Killer Activity in Patients with Chronic Hepatitis Treated with OK432, Interferon, Adenine Arabinoside and Glycyrrhizin. Gastroenterologia Japonica, 22, 312-321.

[178] Edahiro, T., Hamoguchi, M. and Kusuda, R. (1990) Effect of Glycyrrhizin against Streptococcal Infection of Young Yellowtail, Seriola quinqueradiata. Suisanoshiku, 38, 239-243.

[179] Edahiro, T., Hamoguchi, M. and Kusuda, R. (1991) Suppressive Effect of Glycyrrhizin against Streptococcal Infection Promoted by Feeding Oxidized Lipids to Yellowtail, Seriola quinqueradiata. Suisanoshoku, 39, 21-27.

[180] Jang, S.I., Marsden, M.J., Kim, Y.G., Choi, M.S. and Secombes, C.J. (1995) The Effect of Glycyrrhizin on Rainbow Trout, Oncorhynchus mykiss (Walbaum), Leukocyte Responses. Journal of Fish Diseases, 18, 307-315. https://doi.org/10.1111/j.1365-2761.1995.tb00307.x

[181] Rumsey, G.L., Siwicki, A.K., Anderson, D.P. and Bowser, P.R. (1994) Effect of Soyabean Protein on Serological Response, Non-Specific Defense Mechanisms, Growth, and Protein Utilization in Rainbow Trout. Veterinary Immunology and Immunopathology, 41, 323-339. https://doi.org/10.1016/0165-2427(94)90105-8

[182] Grayson, T.H., Williams, R.R., Wrathmell, A.B., Munn, C.B. and Harris, J.E. (1987) Effect of Immunopotentiating Agents on the Immune Response of Rainbow Trout, Salmo gairdneri Richardson to ERM Vaccine. Journal of Fish Biology, 31, 195-202. https://doi.org/10.1111/j.1095-8649.1987.tb05313.x

[183] Ninomiya, M., Hatta, H., Fujiki, M., Kim, M., Yamamoto, T. and Kusuda, R. (1995) Enhancement of Chemotactic Activity of Yellowtail (Seriola quinqueradiata) Leucocytes by Oral Quillaja Saponin. Fish and Shellfish Immunology, 5, 325-328. https://doi.org/10.1006/fsim.1995.0031

[184] Park, K.H. and Jeong, H.D. (1996) Enhanced Resistance against Edwardsiella tarda Infection in (Oreochromis niloticus) by Administration of Protein-Bound Polysaccharide. Aquaculture, 141, 135-143. https://doi.org/10.1016/0044-8486(95)01224-9

[185] Duncan, P.L. and Klesius, P.H. (1996) Effects of Feeding Spirulina on Specific and Nonspecific Immune Responses of Channel Catfish. Journal of Aquatic Animal 
Health, 8, 308-313.

https://doi.org/10.1577/1548-8667(1996)008<0308:EOFSOS>2.3.CO;2

[186] Gildberg, A., Bogwald, J., Johansen, A. and Stenbeg, E. (1996) Isolation of Acid Peptide Fractions from Fish Protein Hydrolysate with Strong Stimulatory Effect on Altantic Salmon (Salmo salar) Head Kidney Leucocytes. Comparative Biochemistry and Physiology, 114B, 97-101. https://doi.org/10.1016/0305-0491(96)00011-9

[187] Dinakaran Michael, R. (2001) Scope for Using Medicinal Plant Extracts as Immunostimulants in Finfish Aquaculture. National Workshop on Aquaculture Medicine, 81-82.

[188] Hemapriya, V.S. (1997) Immunostimulatory Effect of Leaf Extracts of Few Medicinal Plants in Oreochromis mossambicus (Peters). M.Sc. Thesis, The American College, Madurai, India.

[189] Kavitha, K. (1996) Impact of Two Herbs Supplemented Diets on the Growth of Indian Major Carp Labeo rohita (Ham.). M.Sc. Thesis, Maharana Pratap University of Agriculture and Technology, Udaipur, India.

[190] Kumar, A. (2000) Use of Ashwagandha (Withania somnifera L.) Dunal as Growth Promoter in the Supplementary Feed of an Indian Major Carp Cirrhinus mrigala (Ham.). M.Sc. Thesis, MPUAT, Udaipur, India.

[191] Rajkumar (2002) The Effect of Two Herbs Mulethi (Glycyrrhiza glabra Linn.) and Kali Musli (Circuligo orchioides Gaertn.) as Growth Promoter in the Supplementary Feed of an Indian Major Carp Cirrhinus mrigala (Ham.). M.Sc. Thesis, MPUAT, Udaipur, India.

[192] Kour, D. (2003) Use of Herb Bala (Sida cordifolia Linn.) as Growth Promoter in the Supplementary Feed of an Indian Major Carp Cirrhinus mrigala (Ham.). M.Sc. Thesis, MPUAT, Udaipur, India.

[193] Singh, U. (2003) Use of Makhana (Euryale ferox Salisb.) as Growth Promoter in the Supplementary Feed of an Indian Major Carp Cirrhinus mrigala (Ham.). M.Sc. Thesis, MPUAT, Udaipur, India.

[194] Naiyr, P. (2004) Use of Herb Gokhru (Pedalium murex Linn.) as Growth Promoter in the Supplementary Feed of an Indian Major Carp Labeo rohita (Ham.). M.Sc. Thesis, MPUAT, Udaipur, India.

[195] Dhangar, D. (2004) Use of Seed of an Aquatic Herb Lotus (Nelumbium speciosum Wild.) as a Growth Promoter in the Supplementary Feed of an Indian Major Carp Cirrhinus mrigala (Ham.). M.Sc. Thesis, Maharana Pratap University of Agriculture and Technology, Udaipur, India.

[196] Sharma, C., Sharma, L.L. and Sharma, B.K. (2007) The Herb Kaunch (Mucuna pruriens) as Growth Promoter in Supplementary Diet of Common Carp Fingerlings. Fishing Chimes, 26, 69-71.

[197] Won, J., Kim, M., Yi, Y.-W., Kim, Y.H., Jung, N. and Kim, T.K. (2005) A Magnetic Nanoprobe Technology for Detecting Molecular Interactions in Live Cells. Science, 309, 121-125. https://doi.org/10.1126/science.1112869

[198] Bodeker, G., Bhat, K.K.S., Burley, J. and Vantomme, P., Eds. (1997) Medicinal Plants for Forest Conservation and Health Care (Non-Wood Forest Products Serices No. 11). Food and Agriculture Organization of the United Nations, Rome. 
Submit or recommend next manuscript to SCIRP and we will provide best service for you:

Accepting pre-submission inquiries through Email, Facebook, LinkedIn, Twitter, etc. A wide selection of journals (inclusive of 9 subjects, more than 200 journals)

Providing 24-hour high-quality service

User-friendly online submission system

Fair and swift peer-review system

Efficient typesetting and proofreading procedure

Display of the result of downloads and visits, as well as the number of cited articles Maximum dissemination of your research work

Submit your manuscript at: http://papersubmission.scirp.org/

Or contact ajps@scirp.org 